CAHIER DE RECHERCHE \#1619E

WORKING PAPER \#1619E

Département de science économique

Department of Economics

Faculté des sciences sociales

Faculty of Social Sciences

Université d'Ottawa

University of Ottawa

\title{
Terrorism and Employment: Evidence from Successful and Failed Terror Attacks*
}

\author{
Abel Brodeur ${ }^{\dagger}$
}

November 2016

\footnotetext{
*I thank Francesco Amodio, Cristina Blanco-Perez, Pierre Brochu, Marie Connolly, Catherine Deri Armstrong, Jason Garred, David Gray, Catherine Haeck, Anthony Heyes, Julien Martin, Louis-Philippe Morin, Steve Pischke, Francesca Rondina, Yanos Zylberberg and seminar participants at the A3ECQ, CEA, McGill U., UOttawa, UQAM and SCSE for very useful remarks and encouragements. Financial support from SSHRC and the LABEX-OSE is gratefully acknowledged.

${ }^{+}$University of Ottawa, 120 University, Social Sciences Building (9th Floor), Ottawa (ON), Canada K1N 6N5; Email: abrodeur@uottawa.ca.
} 


\begin{abstract}
This paper examines the economic consequences of terror attacks and the channels through which terrorism affects local economies. I rely on an exhaustive list of terror attacks over the period 1970-2013 in the U.S. and exploit the inherent randomness in the success or failure of terror attacks to identify the economic impacts of terrorism. The findings suggest that successful attacks, in comparison to failed attacks, reduce the number of jobs in targeted counties by approximately $4 \%$ in the year the attack takes place. The effects fade away after 2 years and I find no evidence that neighboring counties suffer from the successful attack. Analyzing the channels, I find that successful attacks affect particularly specific industries such as retail trade, finance and real estate. Last, I use data from the Michigan Survey of Consumers and show that successful attacks increase consumers' level of pessimism for their personal finances, business conditions, and buying conditions.
\end{abstract}

Key words: Crime, Terrorism, Employment, Uncertainty, Consumer Sentiment.

JEL Classification: D74, C13, P16. 


\section{Introduction}

Terrorism and its implications on contemporary society has been one of the most discussed issues since Sept. 11, 2001. The notion that terror attacks may have short- and long-run effects on the labor market is not obvious, in part because there are many channels through which terrorism could impact jobs (US Congress (2002)). On the one hand, the rapid recovery from wars and natural disasters led many authors such as British political economist Mill (1848) to argue that nations recover quickly when the direct impacts on productive capital are modest. Becker and Murphy (2001) argue that uncertainty about future terror attacks may increase the complexity of understanding the consequences of terror attacks, but conclude that, ultimately, history shows that economies adjust rapidly. On the other hand, time-series and cross-country studies find that terrorism has heterogeneous impacts on employment and growth (Enders et al. (2016); Gaibulloev et al. (2014)).1. In a seminal paper, Abadie and Gardeazabal (2003) investigate the economic effects of repeated terror attacks in the Basque Country and find that, after the outbreak of terrorism, GDP per capita declined by 10 percentage points relative to the control region.

Identifying the causal impact of terrorism on economic outcomes is difficult for a number of reasons. For instance, economic characteristics of locations targeted by terrorists differ from non-targeted locations (see Section $4]^{2}$ and other economic shocks might affect the local economy simultaneously. In this study, I address these challenges by employing an exhaustive list of terror attacks in the U.S. from 1970 to 2013 and by directly comparing successful terror attacks to failed attacks ${ }^{3}$ Success of terror attacks is defined according to the type of attack (see Section 3). This setting is attractive for at least two reasons. First, the identification assumption is that, conditional on being a location targeted by a terror attack, the success or failure of the attack may be considered as plausibly exogenous. This assumption seems reasonable given that the sample of county-year

\footnotetext{
${ }^{1}$ For instance, see $\overline{\text { Blomberg et al. }}$ (2004), Crain and Crain (2006), Gaibulloev and Sandler (2008), Gries et al. (2011), Meierrieks and Gries (2013) and Tavares (2004). Sandler (2014) provides a literature review. Two papers looking at the effects of terror attacks on local economic activity in Turkey and Italy are respectively Öcal and Yildirim (2010) and Greenbaum et al. (2007).

${ }^{2}$ Counties targeted by a successful terror attack are relatively more populous and have less social security recipients and people in poverty per capita than non-targeted counties. Moreover, counties targeted by a successful terror attack are more likely to be coastal counties, to have an airport and to be in the Western region.

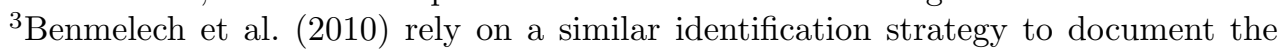
economic consequences of harboring the perpetrators of terror attacks in Palestine.
} 
observations hosting successful and failed terror attacks is balanced across a wide range of characteristics (see Section 4). Moreover, the empirical model controls for attack type, the type of weapon used and the target to proxy for differences in terrorists' tactics. In other words, the empirical model identifies, for instance, the effect of an explosion in which the device detonates versus an explosion in which it does not detonate. Comparing successful and failed terror attacks thus allows me to abstract from the empirical obstacles associated with controlling for all the employment shocks and characteristics of local economies at the moment of the attack.

Second, despite its perceived economic costs in America and the other OECD countries, the study of terrorism using subnational data is a relatively recent phenomenon. The large number of terror attacks and detailed information on their location and date enable me to analyze the economic consequences of terrorism at the county-level. Analyzing the impacts of terror attacks at this geographical level provides a better opportunity to test empirically the channels through which terror affects local economies. The empirical strategy is also aided by the considerable variation across counties in the timing of terror attacks.

Using this identification strategy, I first quantify the economic consequences of terror attacks in targeted areas. In Section 5, I examine whether successful terror attacks cause a decrease in employment in targeted counties. The findings suggest that successful attacks reduce the number of jobs by approximately $4 \%$ in the year the attack takes place in comparison to failed terror attacks. This impact is robust to several specification checks such as the exclusion of catastrophic terror attacks (i.e. Sept. 11, 2001 and Oklahoma City) and the omission of terrorist groups (e.g. Islamic and anti-abortion groups) from the analysis. The results suggest that the reduction in employment lasts for two years and that employment recovers to its pre-attack trend afterward. By contrast, the effects for neighboring counties and non-targeted counties within the same state with an airport are smaller and statistically insignificant suggesting that the employment effects are very local. Last, the estimates yield weak evidence that successful terror attacks affect earnings in the short-run in comparison to failed attacks. The point estimates are smaller than for jobs and statistically significant in only some econometric models.

I then examine the channels through which successful terror attacks temporarily affect local employment. I first test whether the economic effects of terror attacks is related to property damages. I find some evidence that terror attacks leading to a larger decrease in the physical capital stock 
of a county have a greater impact on the number of jobs lost. But the estimates on jobs reduction are certainly too large to imply that terrorism affects employment mainly through property damages.

I then test whether successful attacks affect particularly specific industries such as tourism. The results suggest that the negative impact on employment is especially large for retail trade, services and finance and real estate. I also rely on the presence of an airport as a proxy for the size of the tourism industry and find that jobs-to-population ratios in counties with an airport (medium or major hubs) decrease by approximately $7 \%$ for the year of the attack and the subsequent year. This finding suggests that it takes few years before the psychological effects of terrorism completely wane.

Another plausible channel is the increased (perceived) uncertainty. Becker and Rubinstein (2011) explain that while the likelihood to be harm by a terror attack is extremely low in the U.S., terror may generate an intense fear of future dangers and influence people's behavior. If my results on employment are related to the perceived risk of investing or consuming in the targeted area, then attacks receiving more media coverage should lead to more job losses. I provide evidence that successful attacks receive significantly more coverage than failed attacks using counts of Google searches. The estimates suggest that successful attacks have $70 \%$ more counts of Google searches than failed attacks. These results provide suggestive evidence that people update their beliefs regarding terrorist risk upwards after a successful attacks and fail to incorporate information on failed attacks.

I then explicitly test whether successful attacks affect consumer sentiment. Using data from the Michigan Survey of Consumers, I show that successful attacks increase consumers' level of pessimism for their personal finances, business conditions, and buying conditions. The estimates suggest that successful attacks in comparison to failed attacks increase the likelihood to answer that personal finances are worse off by about $27 \%$, that business conditions are worse by approximately $15 \%$ and that it is a bad time to buy major household items by $10 \%$. The findings are robust to the inclusion of many controls and fixed effects to hold constant other confidence-reducing events. These results are line with the shortterm impact on jobs and provide suggestive evidence that terrorism affects employment through consumer sentiment and uncertainty.

This paper relates to a recent literature that analyzes the economic causes and consequences of terrorism 4 The results highlight some of the

\footnotetext{
${ }^{4}$ See Landes (1978) and Gardeazabal and Sandler 2015) for the effectiveness of coun-
} 
different channels through which terrorism may impact targeted economies. Previous studies provide empirical evidence that terrorism is associated with a decrease in tourist arrivals (Enders et al. (1992)), a decrease in life satisfaction (Frey et al. (2007)), the real estate market Abadie and Gardeazabal (2008); Besley and Mueller (2012); Glaeser and Shapiro (2002)), and net foreign direct investment positions (Abadie and Gardeazabal (2008)). I provide a literature review in Section 2 and turn to a discussion of how my paper complements and contributes to this growing literature in the conclusion 5

Last, my work also complements studies that analyze the impact of uncertainty shocks on consumer spending and employment (e.g. Barsky and Sims (2012); Caggiano et al. (2014); Carroll et al. (1994); Giavazzi and McMahon (2012) ) .6 My estimates of the effect of successful attacks on employment and consumer sentiment contribute to this literature mainly by overcoming the identification problem.

In Section 2, I provide background on the economics of terrorism. Section 3 details the data sets and provides descriptive statistics. Section 4 presents the methodology and the model specification. Section 5 presents the results for jobs. Section 6 examines the channels through which terror attacks affect employment. The last section concludes.

terterrorism policies. Abadie (2006), Enders and Hoover (2012), Krueger and Malečková (2003) and Krueger (2008) for the causes of terrorism. See Di Tella and Schargrodsky (2004), Draca et al. (2011) and Klick and Tabarrok (2005) for the relationship between crime, police and terrorism. Another important and debated theme is the analysis of terrorist attack trends (Enders and Sandler (2005)). Enders et al. (2011) point out many methodological issues of time series analysis such as the importance of separating transnational and domestic terrorist incidents.

${ }^{5}$ This paper also relates to a literature on capital destruction and economic growth. For instance, Deryugina et al. (2014) find temporary negative effects on wages and employment for Katrina victims and provide evidence that their incomes fully recovered within few years and even surpassed that of similar cities not affected by the hurricane. Strobl (2011) finds that a county's annual economic growth rate falls on average by 0.45 percentage points following an hurricane and that the impact is not economically important enough to affect the state-level economy.

${ }^{6}$ See Ludvigson (2004) for a literature review. For instance, Baker et al. (Forthcoming) provide evidence that policy uncertainty is correlated with a reduction in employment and investment in sectors such as finance and construction. Bloom et al. (2007) and Bloom (2009) also provide evidence that the responsiveness of firms is much weaker after major shocks such as Sept. 11, 2001. Last, Abadie and Dermisi (2008) provide evidence that the perceived level of terrorism may affect economic activity in business districts. 


\section{Conceptual Framework}

The effect of successful terror attacks on local employment is, a priori, ambiguous since many channels are at work. A first channel through which terrorism may impact employment is destruction of human and physical capital. Becker and Murphy (2001) estimate that the Sept. 11 attacks resulted in a loss of $0.2 \%$ of physical assets and $0.06 \%$ of total productive assets in the U.S. economy. But most terror attacks in the U.S. do not cause catastrophic building damages. Section 3 documents that, in our data set, the average number of deaths for counties with at least one successful terror attack is 3.8 and very few terror attacks caused over $\$ 1$ billion in property damages. I test whether terror attacks causing more deaths and damages have greater economic impacts in Section 5. Note that terror attacks causing more fatalities and damages may also cause more uncertainty and fear (Becker and Rubinstein (2011))

Increased uncertainty may have an impact on consumer and investment behavior. Investors may move out of riskier assets into safer (US Congress (2002)).7 Capital would tend to flow to destinations without a terrorist threat. I test using data from the Michigan Survey of Consumers whether terrorism affects consumers' attitudes on business conditions and buying conditions. I also provide evidence that successful attacks receive more media attention than failed attacks using counts of Google searches. This is indirect evidence that successful attacks create more fear and uncertainty than failed attacks.

The risk of further incidents may also have psychological effects on potential tourists. A decrease in tourist arrivals following a terror attack has been documented in several studies (see, for instance, Enders et al. (1992) or Sönmez and Graefe (1998)). The psychological effects should wane after some time, but the direct cost of increased airport security could have (worldwide) permanent economic consequences. I check in Section 6 whether successful terror attacks targeting areas with airports have greater economic impacts.

Another channel tested in this paper is migration. Terrorism may worsen individual living and working conditions and might thus impact

\footnotetext{
7 Abadie and Gardeazabal (2008) argue that terrorism may impact the allocation of productive capital across countries. The authors provide evidence that higher levels of terrorist risks are associated with lower levels of net foreign direct investment positions. Terrorism may also cause political instability which would translate into more uncertainty. Jones and Olken (2009) provide evidence that assassinations of political leaders may impact the evolution of political institutions. Their identification strategy relies on the inherent randomness in the success or failure of assassination attempts.
} 
individual migration decision (Dreher et al. (2011)). Moreover, the desire to emigrate (immigrate) might increase (decrease) as a result of the increase in fear and uncertainty. I test this channel in Section 5 and find no evidence that successful terror attacks decrease the number of inhabitants in targeted counties in the years following the attacks.

Terror attacks may also lead to an increase in counterterrorism expenditures (Di Tella and Schargrodsky (2004); Draca et al. (2011)). On the one hand, this increase in counterterrorism expenditures could cause positive employment in sectors such as security. On the other hand, resources would then move out of productive sectors to unproductive sectors. Mueller and Stewart (2014) calculate that domestic counterterrorism expenditures per year were about $\$ 25$ billion in 2010 dollars before the terrorist attacks of Sept. 11, 2001, and increased by about $\$ 75$ billion in the subsequent decade. Note that local employment might not be affected by this channel since counterterrorism expenditures are generally at the national- and regional-levels.

It is possible that the economies of control counties - those with a failed terror attack in our sample period - are affected by failed terror attacks. For example, failed terror attack may increase uncertainty, but it is unlikely that they lead to more fear than successful attacks. Arguably, if the hijackers did not assume control of the planes on Sept. 11, 2001, and did not crash into the World Trade Center, there would have been less uncertainty in the following years. I confirm that successful attacks in comparison to failed attacks receive more media attention and decrease consumer confidence by a larger extent in Section 5 .

\section{Data Sources}

\subsection{Global Terrorism Database}

This study relies on successful and failed terror attacks in the U.S. over the past decades. To establish an exhaustive list of terror attacks, I use the Global Terrorism Database (GTD (2014)), which is an open-source database including information on terror attacks around the world from 1970 through 2013. The GTD is maintained by a research center at the University of Maryland, College Park, the National Consortium for the Study of Terrorism and Responses to Terrorism (START). START is a Department of Homeland Security Center of Excellence which supports research on terrorism. Its main mission is to advance science-based knowl- 
edge about the human causes and consequences of terrorism. Note that the data was originally collected by the Pinkerton Global Intelligence Services for clients interested in knowing the terrorism risk in different countries. The database is the product of important data collection efforts relying on publicly available source materials such as media articles, electronic news archives and existing data sets. Unfortunately, all the records of terror attacks during 1993 were lost — the box of data fell off a truck while in transit (Enders et al. (2011)). As a consequence, the year 1993 is excluded from the analysis.

The GTD (2014) defines a terrorist attack as "the threatened or actual use of illegal force and violence by a non-state actor to attain a political, economic, religious, or social goal through fear, coercion, or intimidation." In practice, an incident is considered a terror attack if (1) it is intentional, (2) it entails some level of violence or threat of violence, and (3) the perpetrators of the incidents are sub-national actors. In addition, two of the three criteria must be fulfilled: (1) the act must be aimed at attaining an economic, political, religious or social goal, (2) there must be evidence of an intention to coerce, intimidate, or convey some other message to a larger audience than the immediate victims, and (3) the action must be outside the context of legitimate warfare activities. In this analysis, I rely solely on terror attacks for which the three criteria above are met. A very similar definition is used in many recent articles analyzing the economic causes and consequences of terrorism. The US Department of State (2003) defines terrorism as "premeditated, politically motivated violence against non-combatant targets by subnational groups or clandestine agents, usually intended to influence an audience."

The database includes information on the date, location and a description of each terror attack, which allows me to match every incident with other data sets. Using the variables collected in the GTD, I construct a variable "Successful" that is equal to one if one of the terror attacks is successful and zero if the $\operatorname{attack}(\mathrm{s})$ failed. Note that I pool all the terror attacks into each county-year cell. If one of the terror attack is successful in a given county-year cell, then the variable "Successful" is equal to one. Terror attacks fail for a number of reasons. Letters containing poison are often intercepted, explosive devices do not detonate or are found and safely defused and targets frequently survive assassination attempts.

The definition of a successful/failed attack depends on the type of attack. For instance, an assassination is considered successful if the target is killed while an explosion is considered successful if the explosive device 
detonates. On the other hand, a hijacking or a kidnapping is successful if the hijackers/kidnappers assume control of the vehicle/individual at any point. An armed assault is coded as successful if the assault takes place and the person or property is hit. An infrastructure attack is successful if the facility is damaged. Last, an unarmed assault is considered successful if a victim is injured.

Figures 1 and 2 illustrate the number of observations per year for Success $=0$ and Success $=1$ and the number of county-year observations with at least one lethal terror attack (i.e. causing at least one death). The number of attempted terror attacks is very high in 1970-1971 and sharply goes down in 1972 8 Overall, there is a downward trend in terror activity over time. The number of failed terror attacks ranges from zero to 14 over this time period ${ }^{9}$ The high number of failed attacks in 1999 (14 observations) and 2002 (12 observations) is due to several related incidents. In May 2002, a college student put eighteen pipe bombs in rural mailboxes, of which more than half did not detonate. In 1999, many researchers in different universities conducting research on non-human primates received booby-trapped letters. The two deadliest terror attacks over this time period are Sept. 11, 2001, and the Oklahoma City bombing.

The database includes information on tactics/attack types used, the weapons used and the targets. In the database, there are nine different categories for attack types, 22 categories of targets including businesses and government buildings, and 13 categories of weapons ranging from biological to incendiary and bombs. The GTD also includes information on the number of deaths, injured and property damages.

\subsection{Description of the Employment Data}

To measure employment and earnings at the county-level for the years 19702013, I draw on the regional economic accounts of the Bureau of Economic Analysis (BEA) 10 The guide "Local Area Personal Income Methodology"

\footnotetext{
${ }^{8}$ The high number of terror attacks in the early 1970 s is due to several nationalist organizations and left-wing militant groups such as the Chicano Liberation Front.

${ }^{9}$ One potential concern with the GTD data is the under-reporting of many failed attacks. This is related to the fact that failed terror attacks not covered by the media are not included in the GTD. Thus, information flows more widely for failed attacks included in the GTD than for attacks not included in this data set. Since one of the main channels through which terrorism affects employment is fear, the under-reporting of failed attacks may lead to a downward bias for my estimates of the impact of successful attacks on employment. See Sections 5 and 6 for more details.

${ }^{10}$ Another data set that could have been used here is the Current Population Survey (CPS), but this was excluded since the sample size does not allow reliable estimates to be obtained at the county-level. Not all counties are included in the CPS and the data
} 
BEA (2014)) presents the conceptual framework and data sources to estimate employment and personal income. The BEA's employment estimates measure the number of jobs in a county, instead of the number of workers who perform the jobs. This means that all jobs held by a worker are counted. The BEA provides total full-time and part-time jobs by industry and compensation of employees. Employment estimates are based primarily on administrative records data. Some surveys and census data are also used to complement these records.

The number of jobs in a county is on a place of work basis instead of place of residence ${ }^{11}$ This suggests that the estimates are more representative of a county's industry base than of the activities of the residents of the county $(\overline{B E A}(2014))$. The employment estimates are annual averages of twelve monthly observations for the year. A job which lasts only part of the year has a lesser weight.

The same weight is given to full-time and part-time jobs. Therefore, I cannot separate part-time jobs from full-time jobs. The BEA counts both proprietors jobs and wage and salary jobs, but unpaid family workers and volunteers are not counted. I calculate jobs-to-population ratios by county and year. In some analysis, I also present results for different industries such as manufacture and service.

Wages and salaries are mainly derived from the data that are reported by place of work. In other words, these data are reported by industry in the county in which the employing establishment is located. Note that wages and salaries are broadly defined to include commissions, tips, and bonuses. The wage and salary estimates also include voluntary employee contributions, gains from exercising stock options and receipts-in-kind that represent income $(\overline{\mathrm{BEA}}(2014))$.

\subsection{Descriptive statistics}

Table 1 reports summary statistics for terror attacks. ${ }^{12}$ I restrict the sample to county-years observations with at least one attempted terror attacks. Appendix Table A1 replicates Table 1, but excludes Sept. 11, 2001 and Oklahoma City bombing. The main variable of interest refers to the per-

are not available for most counties due to confidentiality reasons.

${ }^{11}$ Proprietors' employment is usually by place of residence since the estimates reflect the addresses given in the tax returns, which are usually the proprietors' residences.

12 Brandt and Sandler (2010) note systematic changes in target types over time. Appendix Figures A1, A2 and A3 illustrate the evolution in tactics, weapons used and targets over the period 1970-2013. These figures confirm that terrorists are now more likely to target private parties. 
centage of observations in which there was a successful terror attack(s). I classify county-year observations in two categories: (1) county-year observations in which the terror attack(s) failed and (2) county-year observations in which there was at least one successful terror attacks. Approximately 86 percent of the observations are classified in the second category. Note that there is more than one attempted terror attack in about 30 percent of observations. The average number of deaths and injured for county-year observations classified as successful is respectively 4.2 and 3.4. If Sept. 11, 2001 and Oklahoma City bombing are excluded, the average number of deaths and injured is respectively 2.4 and 0.3 . The mean for property damages (in constant 2005 U.S. dollar) is approximately $\$ 800,000$. Note that the value of property damage is unknown for almost two thirds of terror attacks. Fortunately, another variable in the database provides categorical information for about a quarter of terror attacks for which the exact extent of damages is unknown. The three categories are "Catastrophic (likely greater than $\$ 1$ billion)", "Major (likely greater than $\$ 1$ million but smaller than $\$ 1$ billion)" and "Minor (likely smaller than $\$ 1$ million)." Approximately 40 attacks are classified in the category major.

Up to three attack types and target information can be recorded by incident. This explains why the sum of percentages in Table 1 is often greater than 100. In the vast majority of terror attacks in the U.S., attacks are carried out through the use of explosive and bombs (i.e. bombing) or arson and various forms of sabotage (i.e. infrastructure). The rate of success is very high for attacks in the categories infrastructure and armed assault. On the other hand, attacks considered as unarmed assaults and assassinations are less likely to succeed. Hijackings produce the greatest number of deaths, injuries and damages on average. (Hijackings are included in the category "Other and Unknown".) Infrastructure attacks cause about $\$ 900,000$ in damages on average, but do not lead to many deaths and injuries. About 27 percent of the attacks target businesses. Other common targets include government buildings, abortion clinics and private properties. Attacks targeting airports and government buildings lead, on average, to the greatest number of injured with respectively 11 and 12 against five for businesses. Terror attacks targeting businesses and other private properties cause over $\$ 1$ million worth of damage on average against less than half a million for the following targets: abortion related, airports and religious figures/institutions.

Table 1 shows that the vast majority of weapons are explosives or incendiary. The rate of success is very low for biological weapons, with suc- 
cess in less than half the observations. (Biological weapons are included in the category "Other and Unknown".) These weapons also have a very large number of deaths and injuries. Only 10 percent of the attacks target non-Americans. Approximately 5 percent of the attacks are categorized as logistically international meaning that the nationality of the perpetrator group is not American. Attacks targeting non-Americans and/or in which the nationality of the terrorist group differs from the location of the attacks are defined as transnational terror attacks.

The descriptive statistics presented in this section suggest that the type of terror attack and weapon used are statistically related to rate of success, i.e. whether the terror attack succeeded or failed. The number of attempted attacks in a given county-year is also a good predictor of success. The findings reported in Table 1 also suggest that some type of terror attacks cause more damages while others lead to more injured/deaths on average.

\section{Identification Strategy}

In this section, I first show that locations targeted by terrorists differ from non-targeted locations. I then provide evidence that the sample of successful and failed terror attacks is balanced across a wide range of covariates. Last, I describe the main specification and the controls.

\subsection{Predict Terror Attacks}

I evaluate whether terror attacks are related to observable characteristics in Table 2, Each observation is a county-year cell. Columns 1 and 2 report means and standard deviations for two subsamples. Column 1 restricts the sample to observations with a successful terror attack(s) while column 2 restricts the sample to observations without a terror attack. Time-varying variables are examined in the year before the terror attack(s) took place. The first two columns present the mean values of the following variables: natural log of population, natural log per-capita deaths, births, social security recipients, people in poverty, public school enrollment, violent crimes, robberies, property crimes, motor vehicle thefts, and dummies for state capitals, coastal counties ${ }^{13}$, for counties with an airport that has been desig-

\footnotetext{
${ }^{13}$ I follow the definition of the National Oceanic and Atmospheric Administration and code counties as coastal if they meet one of the following criteria: (1) at least 15 percent of a county's total land area is located within the Nation's coastal watershed or (2) a portion of or an entire county accounts for at least 15 percent of a coastal cataloging unit.
} 
nated large hubs and medium hubs 14 , and for the four Census demographic regions. Column 3 presents $t$-test for the equality of the means.

Results presented in Table 2 suggest that terrorists target non-randomly counties. The difference between columns 1 and 2 is statistically significant at the $1 \%$ level for all the variables tested. More than a third of successful attacks happened in the Western region and about $63 \%$ of successful attacks target coastal counties. Counties with a high number of social security recipients and people in poverty per capita are less likely to be targeted by terrorists. Populous counties and counties with airports are also relatively more targeted by terrorists.

\subsection{Identification Assumption}

The key identification assumption is that the success of a terror attack is exogenous conditional on observables. This explains my decision to control in the empirical model for the type of weapon and the type of attack because they predict success. I investigate in Table 3 whether other variables at the county-level predict whether a terror attack was successful. The first two columns of Table 3 restrict the sample respectively to county-year observations with at least one successful terror attacks and county-year observations with at least one failed terror attacks and no successful terror attack.

While a significant share of terror attacks happened in the West region and in state capitals and coastal counties (Table 2), the results suggest that the rate of success is not related to geography. The differences for the natural log of the number of people in poverty and social security recipients per capita are also non-significant. The only result where the difference between columns 1 and 2 is statistically significant at the $10 \%$ level is property crimes per capita. Note that the difference observed might be related to the type of weapon used or the attack type. Moreover, it is natural that one variable is statistically significant given that 18 variables were tested.

Table 4 shows the results from probit regressions that consider some of these variables simultaneously. The equation is:

$$
P\left(S U C C E S S F U L_{a}\right)=\Phi\left(\gamma_{1}+\gamma_{2} X_{a}\right),
$$

\footnotetext{
${ }^{14}$ Primary airports are classified by the Federal Aviation Administration as large hubs if they account for at least 1 percent of total U.S. passenger enplanements. Medium hubs account for between 0.25 and 1 percent of total U.S. passenger enplanements.
} 
where $a$ is a terror attack, whether successful or failed, and $X$ is a set of variables among the variables considered above. Time-varying variables are examined in the year before the terror attack(s) took place. Unfortunately, some of the variables are available annually solely over the period 1989-2007. I also include in all the columns region fixed effects, attack type fixed effects (dummies for assassination, armed assault, bombing, infrastructure/facility and other attack type), target fixed effects (dummies for abortion related incident, buildings, businesses, educational institution, government, private property and other target), weapon fixed effects (dummies for firearm, explosive, incendiary and other weapon type), a dummy that is equal to one if the target is non-American, a dummy that is equal to one is the attack is logistically international and a variable that is equal to the number of terror attacks.

In column 1, I include time-invariant variables in the model (e.g. capital city) and gradually add socioeconomic characteristics variables and the crime variables in columns 2 and 3 . In column 3, when all the variables are included simultaneously in the model, neither the time-invariant variables nor the socioeconomic characteristics are significantly related to the rate of success. Solely the natural log of property crimes is statistically significant at the $10 \%$ level. When considering all these variables and the regions dummies jointly, the joint $p$-values is 0.47 . These results suggest that the sample of successful and failed terror attacks is balanced across a wide range of covariates and that the identification assumption is credible.

Unsurprisingly, the variable that is equal to the number of attempted terror attacks is statistically significant. I control for the number of attempted attacks in the empirical analysis which follows since the chance of seeing at least one successful terror attacks will increase with the number of terror attempts. In my sample, there is one attempted terror attack for $69 \%$ of county-year cells and less than three attempted terror attacks for $83 \%$ of county-year cells.

The rate of success may also be related to counterterrorism expenses. The rate of success, measured by the variable "Successful", decreased by approximately 8 percent since Sept. 11, 2001, suggesting that the increase in counterterrorism budget might have worked. On the other hand, the rate of success is similar across Census regions suggesting that counterterrorism efforts are not related to geography. In the empirical analysis, I include state fixed effects and interactions between calendar-year dummies and indicator variables denoting the four Census regions to control for local terrorism prevention efforts. 


\subsection{Model Specification}

The objective is to investigate the impact of successful terror attacks. To identify this effect, I restrict the sample to county-year observations with at least one successful terror attacks or at least one failed terror attacks. I thus directly compare county-year observations with at least one successful terror attacks to county-year observations with a failed terror attack. In other words, I look at economic outcomes in two sets of counties that were targeted by terrorists in a given year. The only difference is that the terrorists succeeded in the first set of counties (e.g. the bomb did detonate) and failed in the second set of counties (e.g. the bomb did not detonate).

In my main specification, I estimate:

$$
Y_{c t}=\alpha+\beta_{s}+\delta_{t}+\gamma S U C C E S S F U L_{c t}+X_{c t}^{\prime} \lambda+\varepsilon_{c t},
$$

where $y$ is an economic outcome in county $c$ and year $t, S U C C E S S F U L$ is a dummy that is equal to one if the terror attack was successful in that county and year and zero if the terror attack failed. If there are many terror attacks, SUCCESSFUL is equal to one if at least one of the attacks succeeded. I include state and year fixed effects to control flexibly for common shocks at the national level and to control for common state shocks.

$X_{c t}$ is a vector of other regressors. I include attack type fixed effects and weapon fixed effects since the definition and probability of success depend on the attack type. I follow the recommendations of Bertrand et al. (2004) and compute standard errors clustered at the county-level. I also include a dummy that is equal to one if the target is non-American, a dummy that is equal to one is the attack is logistically international and a variable that is equal to the number of terror attacks ${ }^{15}$

I enrich the basic model in two ways. First, to allow for common regional shocks to a given economic outcome, I estimate specifications that include interactions between year dummies and the four Census regions or the nine Census divisions. Second, I include target fixed effects in addition to attack type and weapon fixed effects.

Estimates of equation (2) identify the difference between successful and failed terror attacks. For example, the estimates identify the impact of an infrastructure attack in which the facility is damaged versus an attack

\footnotetext{
${ }^{15}$ I check the robustness of including the number of terror attacks in different ways. For instance, I check that adding the squared of the number of terror attacks does not affect the size and significance of the main estimates (not shown for space consideration).
} 
in which the facility is not damaged. (See Section 3 for a definition of a success attack for each type of attack.) In the next section, I present the impact of successful terror attacks on employment and earnings.

\section{Results}

\subsection{Impacts on Employment and Earnings}

Panel A of Table 5 presents estimates of equation (2) for jobs. The dependent variable is 100 times the log of the county-year ratio of jobs-topopulation. What emerges clearly is that successful terror attacks are associated with a meaningful reduction in jobs in the year the attacks take place. In column 1, I compare successful and failed terror attacks and find that successful attacks reduce the overall jobs-to-population ratio by $4.3 \%$ in the year the attacks take place. The estimate is statistically significant at the $5 \%$ level. I also add target fixed effects and time-invariant controll ${ }^{16}$ to check the robustness of the results. Furthermore, I include dummies to absorb region-by-year employment shocks (column 3) and Census division-by-year employment shocks (columns 4-5). Adding both dummies to absorb Census division-by-year employment shocks and time-invariant controls (column 5) slightly increases the absolute magnitude of the point estimate to $5.6 \%$.

Panel B repeats these estimates for earnings. The dependent variable is 100 times the log of real average wage per job. These estimates yield weak evidence that successful terror attacks affect earnings in the year the attacks take place. The point estimates are smaller than for jobs (from $2.1 \%$ to $-4.2 \%$ ) and statistically insignificant in the first two columns. When the full set of controls is included in addition to interactions between year dummies and region dummies, the estimate is statistically significant at the $10 \%$ level.

Given the large variation in damages and fatalities in our sample, one potential reason why the estimates are insignificant for earnings is that only terror attacks causing many casualties or building destruction have meaningful impacts on wages. To examine this possibility, I estimate in panel A of Table 6 a set of models that compares successful terror attacks which led to at least one fatality or injury to failed attacks. In panel B, I also present estimates that compare successful terror attacks which led to

\footnotetext{
${ }^{16}$ Time-invariant controls include dummies for coastal counties and being a state capital and a dummy for whether the county has an airport.
} 
a minimum of $\$ 100,000$ (constant 2005 U.S.\$) to failed attacks. I combine the continuous and categorical variables measuring the value of property damage to increase the number of observations. (See Section 3 for more details.) As with the previous models, I control for target fixed effects and include dummies to absorb region-by-year employment shocks (columns 2 and 5) and division-by-year employment shocks (columns 3 and 6). I omit weapon and attack type fixed effects in this set of models because of the high correlation between these variables and damages/fatalities ${ }^{17}$

Panels A and B confirm that, on average, successful terror attacks lead to a reduction in jobs in comparison to failed attacks. The results in panel A suggest that successful attacks which led to at least on fatality or injury reduce the overall jobs-to-population ratio from $5 \%$ to $13 \%$ the year the attack takes place. Of note, though, the standard errors are quite large and the estimates are significant at the 10\% level solely in columns 1 and 2 .

The estimates for damages presented in panel $\mathrm{B}$ are larger than in Table 5 suggesting that the size of the economic effect is related to building damages. The point estimates are all significant for employment and suggest that successful attacks which led to a minimum of $\$ 100,000$ reduce the overall jobs-to-population ratio from $6 \%$ to $12 \%$ in the year the attack takes place. The estimates for earnings are all negative, but statistically significant only in column 4 . Note that the imprecision of the estimates may be due to the poor recording of property damage value in the GTD.

In panel $\mathrm{C}$ and $\mathrm{D}$, I test the indirect effect on counties that were not targeted either successfully or unsuccessfully. In panel C, I use the county adjacency file from the U.S. Census to compute which county or counties are neighboring treated and control counties. I estimate the impact of a successful terror attack versus a failed terror attack on neighboring counties instead of targeted counties. In panel D, I estimate the impact of a successful attack in comparison to a failed attack on non-targeted counties with an airport in the same state as the targeted county. This methodology allows me to check whether terror attacks cause economic spillovers to neighboring counties and non-targeted counties with an airport. The point estimates for employment are small and statistically insignificant at conventional levels, suggesting that only targeted counties suffer from terror attacks. The estimates are also very small for earnings in neighboring

\footnotetext{
${ }^{17}$ I also omit Sept. 11, 2001 and Oklahoma City bombing in Table 6, panel A and B. I check the robustness of my main results to the omission of outliers and subset of years in the next subsection.
} 
counties and insignificant in two columns out of three.

I next estimate the impact of terror attacks on employment levels in the years following and preceding the attack. Table 7 shows estimates for five years before the attack, three years before the attack, one year before the attack, the year of the attack, the year after the attack, three years after the attack and five years after the attack. Each entry is from a separate OLS regression and the dependent variable is the log of the county-year ratio of jobs-to-population.

In panels $\mathrm{A}, \mathrm{B}$ and $\mathrm{C}$, I first check whether terror attacks have an economic impact five years, three years and one year before the attack. This robustness check is useful because it allows to check that counties targeted by a successful terror attack and a failed attack had similar jobsto-population ratio in the years before the attack. Unsurprisingly, the estimates are small and statistically insignificant.

Panel D reports the contemporaneous impacts. The estimates are the same as in Table 5, panel A. The next three panels report the estimates for the years after the terror attacks. The estimates for the year after the attack are strikingly similar to the contemporaneous impacts reported in panel D. The estimates in panels $\mathrm{F}$ and $\mathrm{G}$ provide evidence that the impact of successful terror attacks is temporary and fades away after two years, or that these effects are too small to detect. None of the estimates in panel $\mathrm{F}$ and $\mathrm{G}$ is statistically significant at the $10 \%$ level and the size of the estimates is very small.

I provide a visual summary of the employment impacts in Figure 3. (See Figure 4 for earnings.) This figure plots estimated log jobs-to-population ratios in counties targeted by successful terror attack(s) relative to counties targeted by failed terror attack(s) at yearly intervals in the 5 years prior through the 6 years following the attack. The model includes the full set of controls described previously. The dashed lines represent robust 90\% confidence intervals. As is visible in Figure 3 , relative (log) jobs-topopulation dip by approximately $4 \%$ in the first year following successful terror attacks, reaching a nadir after approximately 12 to 24 months. By contrast, all the estimates for the years before the attack are statistically insignificant.

The results suggests that employment suffers for a short period of time, but eventually converges back to the pre-attack level. These short-term effects are consistent with the idea that local economies recover quickly after a terror attack (Becker and Murphy (2001)). 


\subsection{Robustness Checks}

Thus far, I have relied on all terror attacks over the period 1970-2013 (44 years). As a robustness check, I explore the sensitivity of my results to the omission of a subset of attacks. In Appendix Table A2, I check whether omitting one year of data in the analysis affects the main results on employment. Hence, I tabulate the estimates of 44 OLS regressions. Each entry in the table omits one year of data. As with prior estimates, this sensitivity test indicates that successful attacks in comparison to failed attacks lead to a reduction of the overall jobs-to-population ratio the year of the attack. 42 out of 44 estimates are statistically significant at the $10 \%$ level and the estimates range from $3.5 \%$ to $5.5 \%$. The two estimates (specifications in which the year omitted is 1970 and 1999) not significant at the conventional level are respectively statistically significant at the $11 \%$ and $15 \%$ level. This suggests that my findings are unlikely to be driven by few observations.

So far, the analysis relied on terror attacks from very different groups ranging from anti-abortion groups, to Islamic and environmentalism groups. In Table A3, I test whether my main results are robust to the omission of terror attacks from some of these groups. In column 1, I omit terror attacks from environmentalism and animal protection groups (e.g. Animal Liberation Front). In column 2, I exclude terror attacks from anti-abortion groups. Column 3 excludes terror attacks from Islamic groups (e.g. AlQaeda). In column 4, I exclude terror attacks from environmentalism, animal protection, anti-abortion and Islamic groups. The point estimates for employment are all negative and statistically significant suggesting that none of these groups is driving the main result. The point estimates for earnings are also negative and significant at the $10 \%$ level in columns 2,3 and 4 .

In column 5, I omit terror attacks leading to catastrophic damages (over $\$ 1$ billion) and attacks causing over 100 deaths. The point estimates suggest that successful terror attacks in comparison to failed attacks lead to a decrease of $4 \%$ in jobs in the year of the attack and that earnings decrease by approximately $3 \%$. The estimates are statistically significant and confirm that the results are not driven by outliers.

I check whether successful terror attacks lead to movements out of the county in Appendix Table A4. This is an important robustness check since population was used as a denominator in Table 5 . Moreover, migration is a plausible channel through which terrorism may impact local economies. 
The structure of the table is the same as panel A of Table 5, but the dependent variable is the $\log$ of population. The estimates are all statistically insignificant suggesting that successful terror attacks have no impact on the number of inhabitants in the year of the attack.

\section{Channels}

\subsection{Impacts on Employment by Industry}

I now test whether successful terror attacks affect negatively specific industries. For instance, it is well-known that terrorism is related to the tourism and hotel industries. I test the hypothesis that successful terror attacks in comparison to failed attacks reduce more jobs of local economies with a large tourism industry than other counties in Figure 4. This figure focuses on the sample of counties with an airport that has been designated either a large hub or a medium hub and plots estimates of equation (2) for jobs. Since terror attacks may have psychological effects on potential tourists, contemporaneous estimates and estimates for the years after the attack are presented. The size of the estimates for the year of the attack and the year after the attack are large for counties with an airport and range from $-7.2 \%$ to $-7.5 \%$ for the year of the attack and the year after the attack. The reduction in jobs fades away in the following years and is not statistically significant five years after the successful terror attack.

I also rely on the Standard Industrial Classification (SIC) and provide a visual summary of the employment impacts in Figures 4 and 5 for jobs in the following industries: (1) manufacturing, (2) construction, transportation, communications and utilities, (3) wholesale trade, (4) retail trade, (5) services, and (6) finance, insurance, and real estate. The time period is 1970-2000 and the model includes the full set of controls. As is visible in Figures 4 and 5, jobs in manufacturing, construction, retail trade, services and finance drop in the year of the attack which reinforces the earlier conclusions. But the size of the estimates varies across industries. The impacts of successful terror attacks in comparison to failed attacks are especially large for retail trade and finance, insurance and real estate. On the other hand, there is no effect for employment in wholesale trade.

The results on employment by industry offer some insights on the channels through which successful terror attacks affect local employment. The evidence supports the hypothesis that successful terror attacks have a greater impact on jobs for counties with specific industries such as the 
tourism industry. Furthermore, the results indicate that business disruption caused by a successful attack is particularly harmful for business firms engaged in offering goods and services directly to consumers. This might be related to an increased uncertainty of consuming.

\subsection{Public Awareness and Counts of Google Searches}

I now turn my attention to media coverage and public awareness of terror attacks. Arguably, attacks with more media coverage are other things equal more likely to lead to fear. This fear may be related, for instance, to the belief that a future attack is eminent. In what follows, I rely on counts of Google searches to proxy terrorism coverage. For each attack, I record two counts of Google searches. First, $n$ is equal to the number of searches of the targeted "city", "state" and "year". (For example, for the Boston Marathon bombing, I compute the number of searches for "Boston Massachusetts 2013".) This first indicator is included in the empirical model to control for scale effects (DellaVigna and La Ferrara (2010)). Second, Terror Searches is equal to the counts of Google searches for the words "city", "state", "year" and "terrorism".

For this analysis, I restrict the time period to 1994-2012 and omit terror attacks which took place in 2001 since measurement error may be large for events not related to Sept. 11, 2001. The model is similar to equation (2) but the dependent variable is now the log of Terror Searches $s_{c t}$ in county $c$ and year $t$ and I control for the $\log$ of $n_{c t}$. The estimates are presented in Table 8. The findings suggest that successful attacks in comparison to failed attacks have approximately 50-70\% more counts of Google searches. Including dummies to absorb region-by-year shocks and Census divisionby-year shocks slightly increases the size of the estimates.

The result that successful attacks have more counts of Google searches than failed attacks is consistent with the idea that successful attacks lead to more uncertainty. This is an important result since uncertainty has been shown to be related to the likelihood to consume and expand businesses (see Bloom (2009) for example).

\subsection{Terrorism and Consumer Sentiment}

In this subsection, I test explicitly whether successful attacks affect consumer sentiment. More precisely, I test whether successful attacks impact contemporaneous attitudes toward personal finances, business and buying conditions. For this analysis, I rely on microdata from the Michigan Sur- 
vey of Consumers (MSC), conducted by the Survey Research Center at the University of Michigan. The MSC assesses consumer attitudes on personal finances, business conditions and buying conditions, and is widely used to gauge consumers' level of pessimism and expectations of spending and saving behavior 18

For this research, I obtained monthly data at the county-level for the 2000-2012 surveys from the University of Michigan Survey Research Center. The monthly MSC is an ongoing nationally representative survey of at least 500 consumers 19

I check in Table 9 whether consumer sentiment changes following a successful terror attack in comparison to a failed attack. The dependent variables from the MSC are based on answers from the following questions: [1] "We are interested in how people are getting along financially these days. Would you say that you are better off or worse off financially than you were a year ago?", [2] "Would you say that at the present time business conditions are better or worse than they were a year ago?", [3] "Now looking ahead-do you think that a year from now you will be better off financially, or worse off, or just about the same as now?" and [4] "About the big things people buy for their homes-such as furniture, a refrigerator, stove, television, and things like that. Generally speaking, do you think now is a good or a bad time for people to buy major household items?" I code the variables as dummies. For the first question, the dependent variable is equal to one if respondents report "Worse" and zero if respondents report "Better now" or "Same". For the second question, the dependent variable is equal to one if respondents report "Worse now" and zero if they report "Better now" or "About the same". For the third question, the dependent variable is equal to one if respondents report "Will be worse off" and zero otherwise. Last, the dependent variable for the fourth question is equal to one if respondents report "Bad" and zero otherwise.

The model is similar to equation (2) with the exception that the unit of observation is now the individual. I also control for the individual's

\footnotetext{
${ }^{18}$ The widely reported Index of Consumer Sentiment (ICS) is derived from five questions covering three broad areas of consumer sentiment: personal finances, business conditions, and buying conditions. See https : //data.sca.isr.umich.edu/fetchdoc.php?docid $=24770$ for the index calculations and the questions.

${ }^{19}$ The sample incorporates a rotating panel sample design. Every month, an independent cross-section sample of households is drawn. The respondents are then reinterviewed six months later (Curtin (1982)).
} 
demographic characteristics. Specifically, I estimate:

$$
Y_{i c t}=\alpha+\beta_{s}+\delta_{t}+\gamma S U C C E S S F U L_{c t}+\lambda X_{c t}+\theta Z_{i c t}+\varepsilon_{i c t},
$$

where $y$ is an economic sentiment for individual $i$ in county $c$ and year $t$ and $Z_{i c t}$ is a vector of individual characteristics. These characteristics include the individual's gender, age, age squared, five education dummies and five marital status dummies.

The model also includes year fixed effects to control flexibly for common shocks to national consumer confidence and state fixed effects to control for differences in consumer confidence across states. The inclusion of a set of time dummies is very important since there could be other confidencereducing events at the federal-level (e.g. variation in international oil prices or in the stock market indexes).

Table 9 shows the results from probit regressions. In this table, I compare answers of respondents living in counties targeted by successful and failed terror attacks the year of the attack. In columns 1 and 2, I test whether respondents think that their personal finances and business conditions are worse now in comparison to a year ago. Since I use data for the year of the attack, positive estimates suggest that respondents think that their personal finances and business conditions are worse than before the terror attack. In column 1, I find that successful attacks increase the likelihood to answer that personal finances are worse off than a year ago by about $27 \%$. The estimates are positive and statistically significant at the $1 \%$ level. Column 2 finds that respondents living in counties targeted by a successful attack are more likely to answer that business conditions are worse now. The estimate is significant at the $1 \%$ level and suggests that successful attacks increase the likelihood to answer that business conditions are worse by approximately $15 \%$.

In column 3, I test whether respondents think that their personal finances will be worse in a year from now. A positive estimate would suggest that respondents in counties targeted by a successful attack are more likely think that they will be worse off financially in a year from now. I do not find evidence that this is the case. The estimate is positive, but not statistically significant at the $10 \%$ level.

In column 4, the dependent variable is whether it is a bad time for people to buy major household items. The estimate is positive and significant at the $1 \%$ level indicating that successful attacks increase the likelihood to answer that it is a bad time to buy big things such as furniture, a refriger- 
ator, stove, television, and things like that for their homes. More precisely, the estimate suggests that successful attacks increase the likelihood to answer that it is a bad time by approximately $10 \%$.

Overall, I find evidence that successful terror attacks affect attitudes toward personal finances, business and buying conditions in the year of the attack. These results suggest that consumer sentiment is down for counties targeted by successful attacks and that consumers living in those counties think it is not a good moment to spend money. These findings are in line with the short-term impact on jobs documented in the previous section.

\section{Conclusion}

In this paper I identify the impact of terrorism on local economies by exploiting the inherent randomness in the success or failure of terror attacks. There are two main empirical results. First, successful terror attacks reduce the overall jobs-to-population ratio by approximately $4 \%$ in the year the attack takes place in comparison to failed terror attacks. But I find no evidence that successful terror attacks have long-term consequences on local economies. Employment in counties with a successful attack converges back to the pre-attack trend after few years.

Second, I document the channels through which terrorism affects employment. I provide evidence that successful terror attacks affect particularly specific industries such as tourism and retail trade. Furthermore, I have found a number of regularities in my analysis of the effect of terrorism on people's attitudes toward personal finances and economic conditions. For example, I found that successful terror attacks in comparison to failed attacks increase the likelihood of the county population to report that business and buying conditions are worse than they were before the attack.

The findings seem to confirm that economies adjust rapidly to terror attacks (Becker and Murphy (2001)). The results also provide suggestive evidence that terror attacks affect temporarily employment mainly through consumer sentiment and uncertainty. In other words, fear of consuming or investing plays an important role in explaining the temporary decrease in employment following a successful terror attack (Becker and Rubinstein (2011)).

I believe further research is needed in at least two dimensions. From my results, I cannot conclude on whether a region subject to repeated terror attacks suffer economically. In order to answer this question, other identification strategies may be better suited (Abadie and Gardeazabal (2003)). 
In addition, more work is needed on the national consequences of terrorism such as the rise of counterterrorism expenditures and the increased airport security. 


\section{References}

Abadie, A.: 2006, Poverty, Political Freedom, and the Roots of Terrorism, American Economic Review, Papers and Proceedings 96(2), 50-56.

Abadie, A. and Dermisi, S.: 2008, Is Terrorism Eroding Agglomeration Economies in Central Business Districts? Lessons from the Office Real Estate Market in Downtown Chicago, Journal of Urban Economics 64(2), 451-463.

Abadie, A. and Gardeazabal, J.: 2003, The Economic Costs of Conflict: A Case Study of the Basque Country, American Economic Review 93(1), 113-132.

Abadie, A. and Gardeazabal, J.: 2008, Terrorism and the World Economy, European Economic Review 52(1), 1-27.

Baker, S. R., Bloom, N. and Davis, S. J.: Forthcoming, Measuring Economic Policy Uncertainty, Quarterly Journal of Economics .

Barsky, R. B. and Sims, E. R.: 2012, Information, Animal Spirits, and the Meaning of Innovations in Consumer Confidence, American Economic Review 102(4), 1343-1377.

BEA: 2014, Local Area Personal Income Methodology, Regional Economic Accounts, November.

Becker, G. and Murphy, K.: 2001, Prosperity Will Rise Out of the Ashes, Wall Street Journal: October 29, 2001.

Becker, G. S. and Rubinstein, Y.: 2011, Fear and the Response to Terrorism: An Economic Analysis. Centre for Economic Performance Working Paper 1079.

Benmelech, E., Berrebi, C. and Klor, E. F.: 2010, The Economic Cost of Harboring Terrorism, Journal of Conflict Resolution 54(2), 331-353.

Bertrand, M., Duflo, E., Mullainathan, S. et al.: 2004, How Much Should we Trust Differences-in-Differences Estimates?, Quarterly Journal of Economics 119(1), 249-275.

Besley, T. and Mueller, H.: 2012, Estimating the Peace Dividend: The Impact of Violence on House Prices in Northern Ireland, American Economic Review 102(2), 810-833. 
Blomberg, S. B., Hess, G. D. and Orphanides, A.: 2004, The Macroeconomic Consequences of Terrorism, Journal of Monetary Economics 51(5), 1007-1032.

Bloom, N.: 2009, The Impact of Uncertainty Shocks, Econometrica $77(3), 623-685$.

Bloom, N., Bond, S. and Van Reenen, J.: 2007, Uncertainty and Investment Dynamics, Review of Economic Studies 74(2), 391-415.

Brandt, P. T. and Sandler, T.: 2010, What do Transnational Terrorists Target? Has It Changed? Are we Safer?, Journal of Conflict Resolution $\mathbf{5 4}(2), 214-236$.

Caggiano, G., Castelnuovo, E., Groshenny, N. et al.: 2014, Uncertainty Shocks and Unemployment Dynamics in US Recessions, Journal of Monetary Economics 67(C), 78-92.

Carroll, C. D., Fuhrer, J. C. and Wilcox, D. W.: 1994, Does Consumer Sentiment Forecast Household Spending? If so, Why?, American Economic Review 84(5), 1397-1408.

Crain, N. V. and Crain, W. M.: 2006, Terrorized Economies, Public Choice 128(1), 317-349.

Curtin, R. T.: 1982, Indicators of Consumer Behavior: The University of Michigan Surveys of Consumers, Public Opinion Quarterly 46(3), 340352 .

DellaVigna, S. and La Ferrara, E.: 2010, Detecting Illegal Arms Trade, American Economic Journal: Economic Policy 2(4), 26-57.

Deryugina, T., Kawano, L. and Levitt, S.: 2014, The Economic Impact of Hurricane Katrina on its Victims: Evidence from Individual Tax Returns. NBER Working Paper 20713.

Di Tella, R. and Schargrodsky, E.: 2004, Do Police Reduce Crime? Estimates Using the Allocation of Police Forces After a Terrorist Attack, American Economic Review 94(1), 115-133.

Draca, M., Machin, S. and Witt, R.: 2011, Panic on the Streets of London: Police, Crime, and the July 2005 Terror Attacks, American Economic Review 101(5), 2157-2181. 
Dreher, A., Krieger, T. and Meierrieks, D.: 2011, Hit and (they Will) Run: The Impact of Terrorism on Migration, Economics Letters 113(1), 42-46.

Enders, W. and Hoover, G. A.: 2012, The Nonlinear Relationship Between Terrorism and Poverty, American Economic Review, Papers and Proceedings 102(3), 267-272.

Enders, W., Hoover, G. A. and Sandler, T.: 2016, The Changing Nonlinear Relationship Between Income and Terrorism, Journal of Conflict Resolution 60(2), 195-225.

Enders, W. and Sandler, T.: 2005, After 9/11 Is It All Different Now?, Journal of Conflict Resolution 49(2), 259-277.

Enders, W., Sandler, T. and Gaibulloev, K.: 2011, Domestic Versus Transnational Terrorism: Data, Decomposition, and Dynamics, Journal of Peace Research 48(3), 319-337.

Enders, W., Sandler, T. and Parise, G. F.: 1992, An Econometric Analysis of the Impact of Terrorism on Tourism, Kyklos 45(4), 531-554.

Frey, B. S., Luechinger, S. and Stutzer, A.: 2007, Calculating Tragedy: Assessing the Costs of Terrorism, Journal of Economic Surveys 21(1), 124.

Gaibulloev, K. and Sandler, T.: 2008, Growth Consequences of Terrorism in Western Europe, Kyklos 61(3), 411-424.

Gaibulloev, K., Sandler, T. and Sul, D.: 2014, Dynamic Panel Analysis Under Cross-Sectional Dependence, Political Analysis 22(2), 258-273.

Gardeazabal, J. and Sandler, T.: 2015, INTERPOL's Surveillance Network in Curbing Transnational Terrorism, Journal of Policy Analysis and Management 34(4), 761-780.

Giavazzi, F. and McMahon, M.: 2012, Policy Uncertainty and Household Savings, Review of Economics and Statistics 94(2), 517-531.

Glaeser, E. L. and Shapiro, J. M.: 2002, Cities and Warfare: The Impact of Terrorism on Urban Form, Journal of Urban Economics 51(2), 205-224.

Greenbaum, R. T., Dugan, L. and LaFree, G.: 2007, The Impact of Terrorism on Italian Employment and Business Activity, Urban Studies 44(56), 1093-1108. 
Gries, T., Krieger, T. and Meierrieks, D.: 2011, Causal Linkages Between Domestic Terrorism and Economic Growth, Defence and Peace Economics 22(5), 493-508.

GTD: 2014, National Consortium for the Study of Terrorism and Responses to Terrorism (START), Global Terrorism Database: Retrieved from http://www.start.umd.edu/gtd.

Jones, B. F. and Olken, B. A.: 2009, Hit or Miss? The Effect of Assassinations on Institutions and War, American Economic Journal: Macroeconomics $\mathbf{1}(2), 55-87$.

Klick, J. and Tabarrok, A.: 2005, Using Terror Alert Levels to Estimate the Effect of Police on Crime, Journal of Law and Economics 48(1), 267-279.

Krueger, A. B.: 2008, What Makes a Terrorist: Economics and the Roots of Terrorism, Princeton University Press.

Krueger, A. B. and Malečková, J.: 2003, Education, Poverty and Terrorism: Is There a Causal Connection?, Journal of Economic Perspectives 17(4), 119-144.

Landes, W. M.: 1978, An Economic Study of US Aircraft Hijacking, 19611976, Journal of Law and Economics 21(1), 1-31.

Ludvigson, S. C.: 2004, Consumer Confidence and Consumer Spending, Journal of Economic Perspectives 18(2), 29-50.

Meierrieks, D. and Gries, T.: 2013, Causality Between Terrorism and Economic Growth, Journal of Peace Research 50(1), 91-104.

Mill, J. S.: 1848, Principles of Political Economy, JW Parker.

Mueller, J. and Stewart, M. G.: 2014, Evaluating Counterterrorism Spending, Journal of Economic Perspectives 28(3), 237-48.

Öcal, N. and Yildirim, J.: 2010, Regional Effects of Terrorism on Economic Growth in Turkey: A Geographically Weighted Regression Approach, Journal of Peace Research 47(4), 477-489.

Sandler, T.: 2014, The Analytical Study of Terrorism: Taking Stock, Journal of Peace Research 51(2), 257-271.

Sönmez, S. F. and Graefe, A. R.: 1998, Influence of Terrorism Risk on Foreign Tourism Decisions, Annals of Tourism Research 25(1), 112-144. 
Strobl, E.: 2011, The Economic Growth Impact of Hurricanes: Evidence from U.S. Coastal Counties, Review of Economics and Statistics 93(2), 575-589.

Tavares, J.: 2004, The Open Society Assesses its Enemies: Shocks, Disasters and Terrorist Attacks, Journal of Monetary Economics 51(5), 10391070 .

US Congress: 2002, The Economic Costs of Terrorism, United States Congress, Joint Economic Committee.

US Department of State: 2003, Patterns of Global Terrorism: 2002, Washington, DC: US Department of State. 


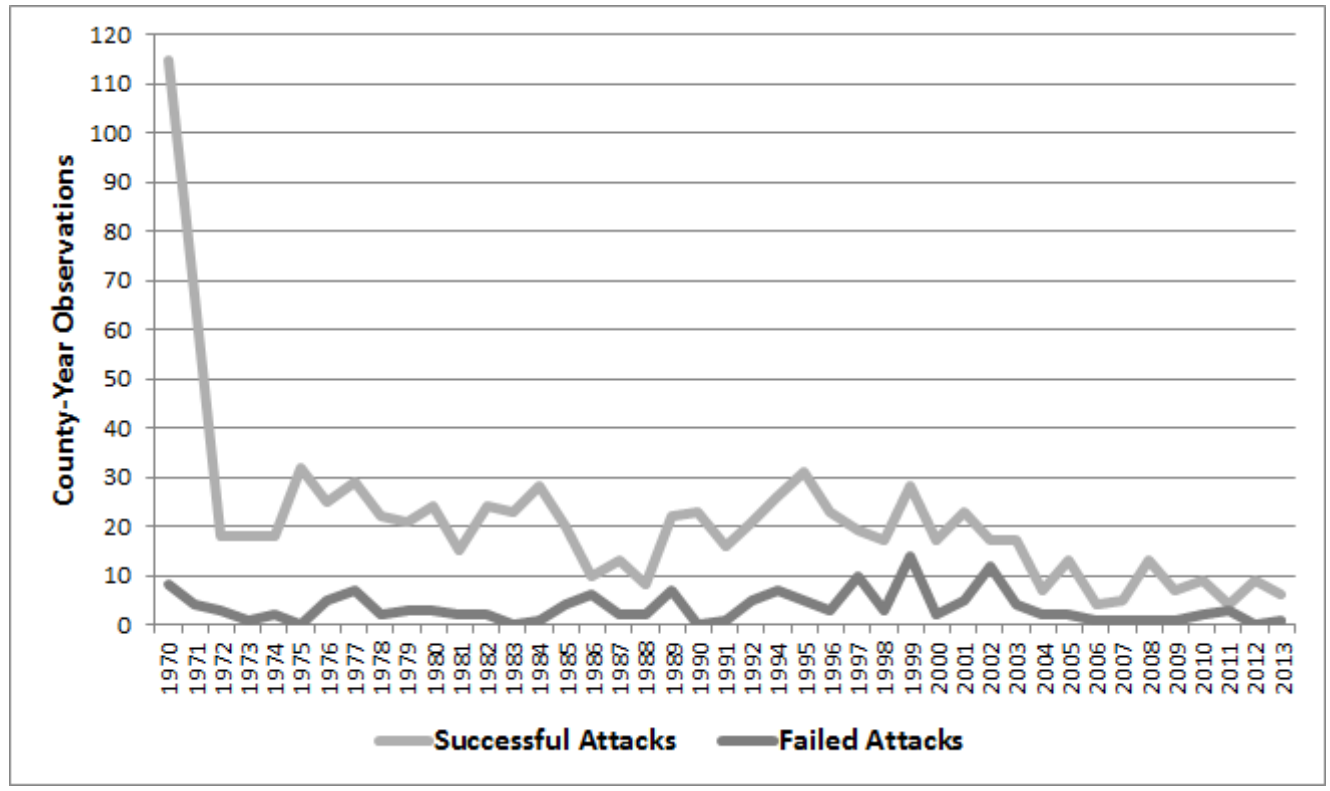

Figure 1: Number of county-year observations with at least one successful terror attack and the number of county-year observations with at least one failed terror attack and no successful terror attack.

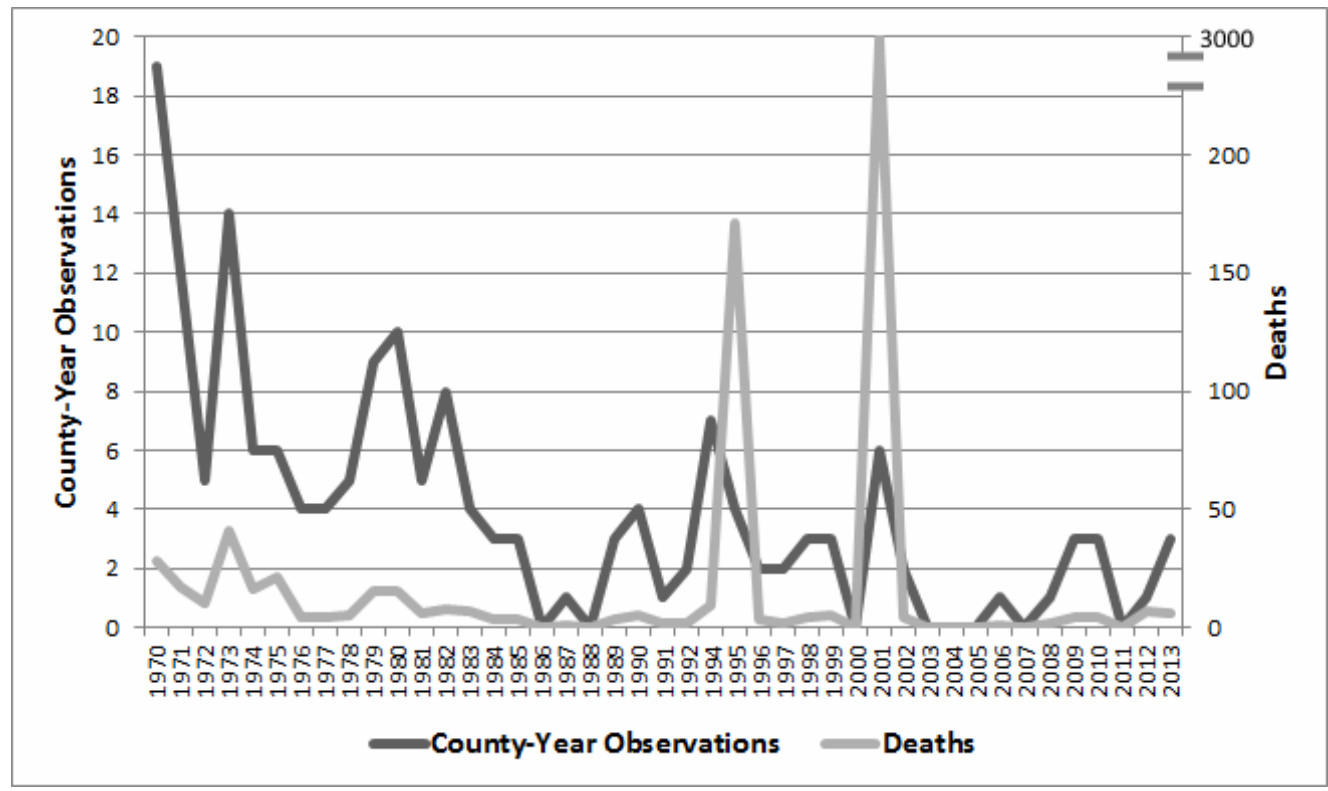

Figure 2: Number of county-year observations with at least one lethal terror attack (i.e. causing at least one death) and the number deaths caused by terror attacks. See Section 3 for more details. 


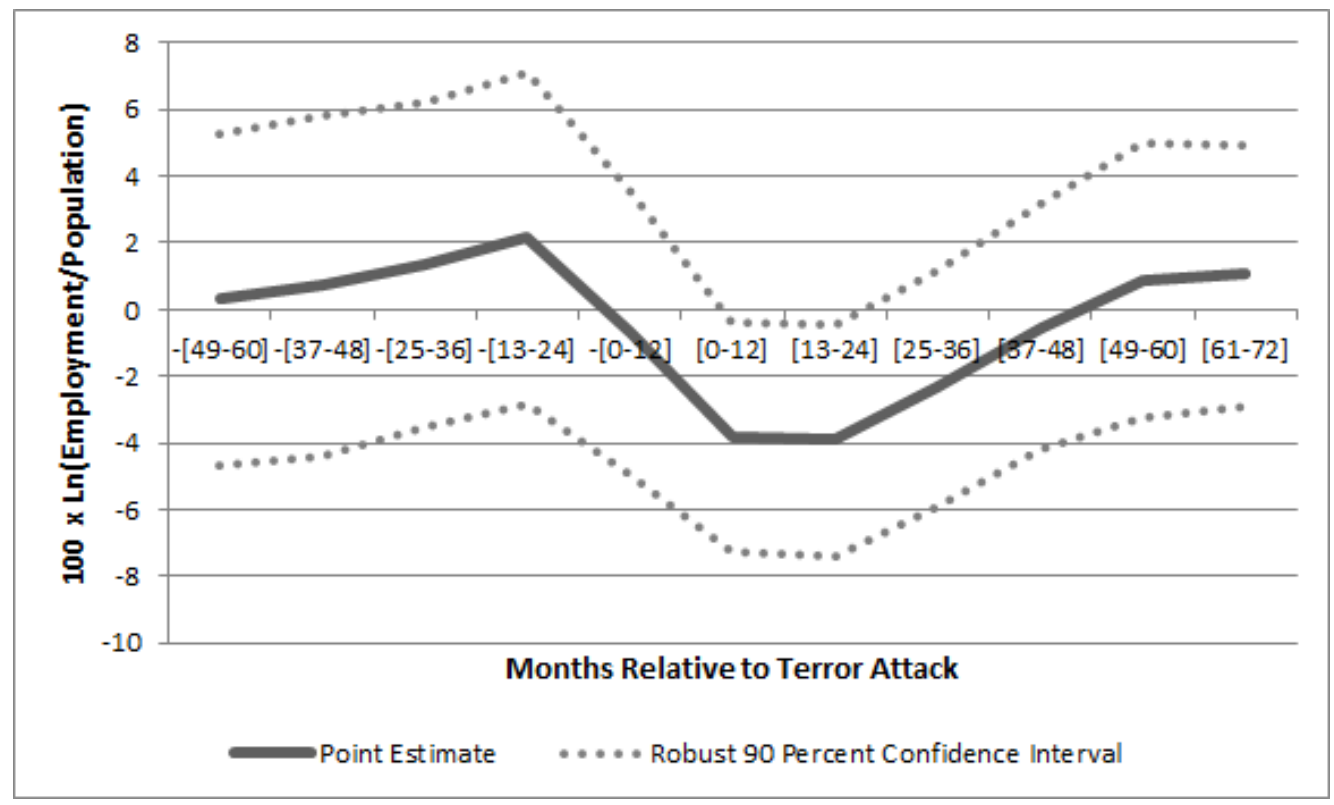

Figure 3: This figure plots estimated log jobs-to-population ratios in counties targeted by successful terror attack(s) relative to counties targeted by failed terror attack(s) at yearly intervals in the five years prior through the six years following the attack. See Section 5 and Table 7 for more details. The empirical model controls for attack type, the type of weapon used and target fixed effects. Additional controls include state and year fixed effects, time-invariant controls, a dummy that is equal to one if the target is non-American, a dummy that is equal to one if the attack is logistically international and a variable that is equal to the number of terror attacks. 


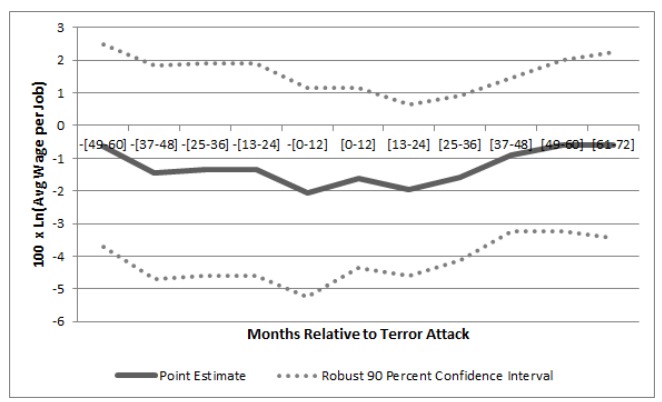

(a) Average Wage per Job

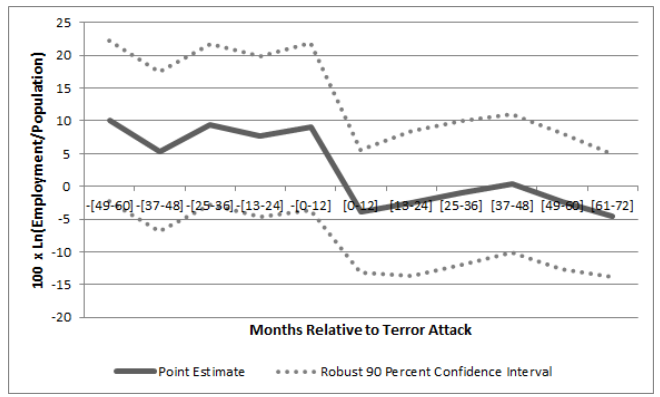

(c) Jobs in Manufacture

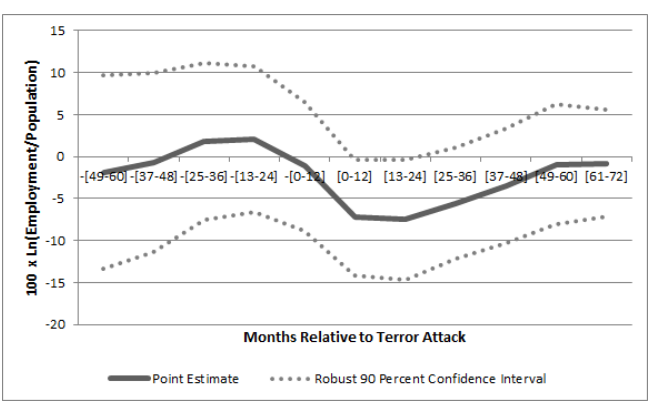

(b) Jobs in Counties with an Airport

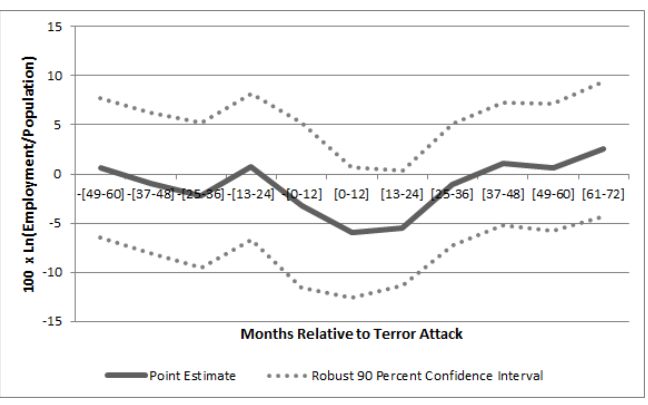

(d) Jobs in Construction \& Transportation

Figure 4: Sub-figure (a) plots estimated log of the county real average wage per job in counties targeted by successful terror attack(s) relative to counties targeted by failed terror attack(s) at yearly intervals in the five years prior through the six years following the attack. Sub-figure (b) restricts the sample to counties with an airport and plots estimated log jobs-to-population ratios in counties targeted by successful terror attack(s) relative to counties targeted by failed terror attack(s) at yearly intervals. Sub-figure (c) plots estimated log manufacturing jobs-to-population ratios in counties targeted by successful terror attack(s) relative to counties targeted by failed terror attack(s) at yearly intervals. Sub-figure (d) plots estimated $\log$ construction jobs-to-population ratios in counties targeted by successful terror attack(s) relative to counties targeted by failed terror attack(s) at yearly intervals. See Section 6 and Table 7 for more details. 


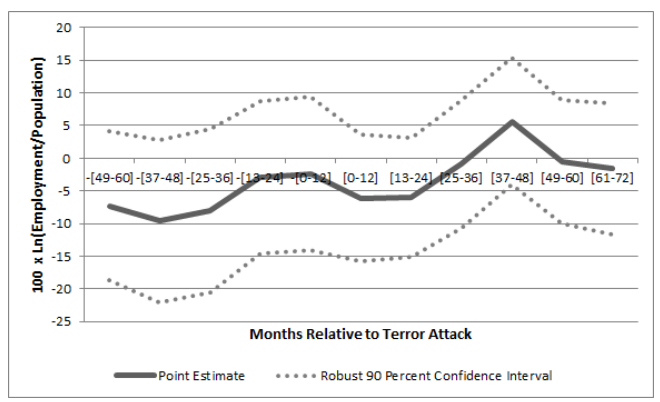

(a) Jobs in Wholesale Trade

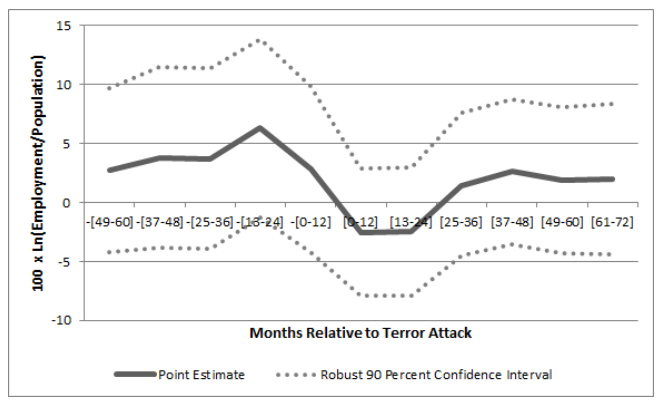

(c) Jobs in Services

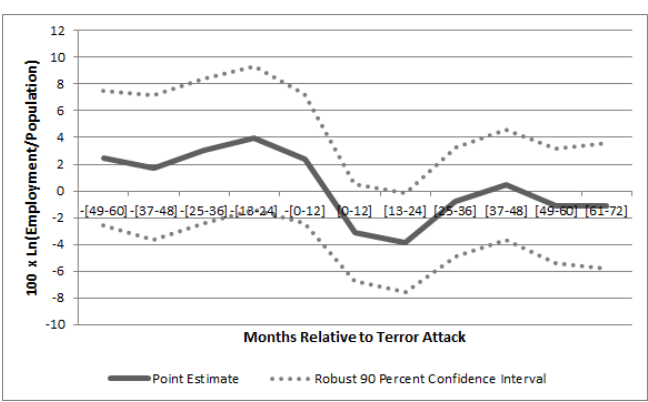

(b) Jobs in Retail Trade

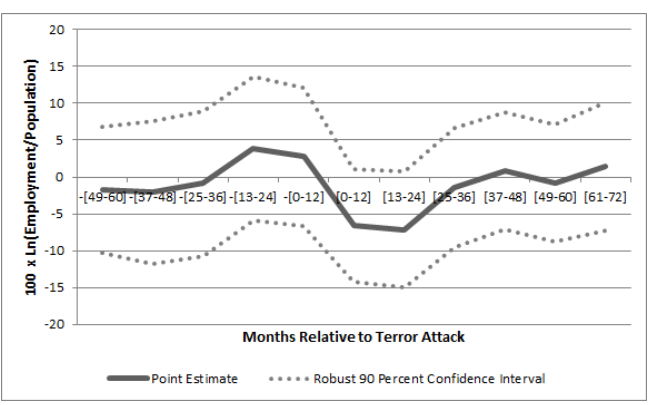

(d) Jobs in Finance \& Real Estate

Figure 5: Sub-figure (a) plots estimated log wholesale trading jobs-topopulation ratios in counties targeted by successful terror attack(s) relative to counties targeted by failed terror attack(s) at yearly intervals in the five years prior through the six years following the attack. Sub-figure (b) plots estimated log retail trading jobs-to-population ratios in counties targeted by successful terror attack(s) relative to counties targeted by failed terror attack(s) at yearly intervals. Sub-figure (c) plots estimated log service jobs-to-population ratios in counties targeted by successful terror attack(s) relative to counties targeted by failed terror attack(s) at yearly intervals. Sub-figure (d) plots estimated log finance, insurance and real estate jobs-topopulation ratios in counties targeted by successful terror attack(s) relative to counties targeted by failed terror attack(s) at yearly intervals. See Section 6 and Table 7 for more details. 
Table 1: Terror Attacks: Descriptive Statistics

\begin{tabular}{|c|c|c|c|c|c|c|}
\hline & \multirow[b]{2}{*}{ Observation } & \multirow[b]{2}{*}{ Percentage } & \multirow{2}{*}{$\begin{array}{c}\text { Attack } \\
\text { Success }\end{array}$} & \multicolumn{3}{|c|}{ If Attack Successful (mean) } \\
\hline & & & & Injured & Killed & Damage \\
\hline \multicolumn{7}{|l|}{ Attack Type } \\
\hline Assassination & 70 & $7.3 \%$ & $77.1 \%$ & 0.76 & 1.26 & 150,667 \\
\hline Armed Assault & 115 & $12.0 \%$ & $95.7 \%$ & 3.86 & 28.49 & 484,901 \\
\hline Bombing & 420 & $43.8 \%$ & $81.9 \%$ & 4.47 & 0.79 & 669,620 \\
\hline Infrastructure & 460 & $47.9 \%$ & $93.5 \%$ & 0.87 & 0.14 & 895,242 \\
\hline Unarmed & 34 & $3.5 \%$ & $52.9 \%$ & 48.35 & 153.89 & 2,946 \\
\hline \multirow[t]{3}{*}{ Other \& Unknown } & 35 & $3.6 \%$ & $94.3 \%$ & 4.53 & 91.58 & 360,750 \\
\hline & & & Attack & \multicolumn{3}{|c|}{ If Attack Successful (mean) } \\
\hline & Observations & Percentage & Success & Injured & Killed & Damage \\
\hline \multicolumn{7}{|l|}{ Target } \\
\hline Business & 258 & $26.9 \%$ & $92.2 \%$ & 4.97 & 12.09 & $1,286,966$ \\
\hline Government & 177 & $18.4 \%$ & $79.7 \%$ & 12.14 & 3.14 & 582,233 \\
\hline Abortion Related & 168 & $17.5 \%$ & $88.1 \%$ & 0.16 & 0.03 & 184,814 \\
\hline Airport & 36 & $3.8 \%$ & $88.9 \%$ & 10.84 & 94.66 & 482,102 \\
\hline Educational Inst & 100 & $10.4 \%$ & $81.0 \%$ & 1.73 & 0.25 & $1,027,569$ \\
\hline Private Property & 183 & $19.1 \%$ & $86.9 \%$ & 3.63 & 18.41 & $1,200,410$ \\
\hline Religious Inst & 57 & $5.9 \%$ & $89.5 \%$ & 0.71 & 0.69 & 496,292 \\
\hline \multirow[t]{3}{*}{ Other \& Unknown } & 269 & $28.0 \%$ & $90.3 \%$ & 5.65 & 12.79 & 482,688 \\
\hline & & & Attack & \multicolumn{3}{|c|}{ If Attack Successful (mean) } \\
\hline & Observations & Percentage & Success & Injured & Killed & Damage \\
\hline \multicolumn{7}{|l|}{ Weapon } \\
\hline Firearms & 161 & $16.8 \%$ & $90.7 \%$ & 2.17 & 1.19 & 429,687 \\
\hline Explosives & 420 & $43.8 \%$ & $82.1 \%$ & 4.49 & 0.82 & 686,490 \\
\hline Incendiary & 441 & $45.9 \%$ & $93.4 \%$ & 0.90 & 7.44 & 928,632 \\
\hline Melee & 29 & $3.0 \%$ & $96.6 \%$ & 6.04 & 108.00 & 362,142 \\
\hline Sabotage & 28 & $2.9 \%$ & $96.4 \%$ & 4.04 & 0.11 & 352,232 \\
\hline Other \& Unknown & 171 & $17.8 \%$ & $77.2 \%$ & 8.90 & 23.84 & 880,784 \\
\hline Multiple Attacks & 302 & $31.5 \%$ & $94.0 \%$ & 5.37 & 10.23 & 842,006 \\
\hline Target Non-US & 84 & $8.8 \%$ & $88.1 \%$ & 3.13 & 0.81 & 424,348 \\
\hline Logistic Int'l & 49 & $5.1 \%$ & $83.7 \%$ & 2.76 & 0.66 & 680,512 \\
\hline Total Observations & 960 & & $85.7 \%$ & 3.36 & 4.18 & 791,183 \\
\hline
\end{tabular}

Notes: There are a total of 960 county-year observations. In this table, the variable "Multiple Attacks" equals one if there is more than one terror attack in a given county-year cell. For some terror attacks, multiple weapons were used. Moreover, up to three attack types and target information can be recorded by incident. Weapons classified as "Others \& Unknown" are either (1) weapons that have been identified but does not fit into one of the categories or (2) weapons that could not have been identified. Targets classified as "Others \& Unknown" include media, military, NGO, police, telecommunication, tourists, transportation and attacks carried out against foreign missions, maritime facilities, non-state militias, violent political parties, utilities and food or water supply. Note that an unarmed assault is an attack whose primary objective is to cause physical harm or death directly. Unarmed assaults include chemical, biological and radiological weapons but exclude explosive, firearm and incendiary. Attacks classified as infrastructure refers to an act whose primary objective is to cause damage to a non-human target (building, monument, train or pipeline). The attack type "Hijacking" is included in the category "Other \& Unknown". The last three columns restrict the sample to successful terror attacks. Property damages are in constant 2005 U.S. dollar. 


\begin{tabular}{|c|c|c|c|}
\hline & $\begin{array}{c}\text { Successful } \\
(1)\end{array}$ & $\begin{array}{c}\text { Other Counties } \\
(2) \\
\end{array}$ & $\begin{array}{c}\text { Difference } \\
(3)\end{array}$ \\
\hline \multicolumn{4}{|l|}{ Two-Sided $t$-tests } \\
\hline State Capital & $0.13(0.34)$ & $0.02(0.13)$ & $0.114(0.004)$ \\
\hline Coastal County & $0.63(0.48)$ & $0.21(0.41)$ & $0.414(0.014)$ \\
\hline Airport (Large Hub) & $0.29(0.46)$ & $0.01(0.11)$ & $0.281(0.004)$ \\
\hline Airport (Medium Hub) & $0.14(0.35)$ & $0.01(0.11)$ & $0.130(0.004)$ \\
\hline Log Population & $12.99(1.41)$ & $10.17(1.38)$ & $2.820(0.048)$ \\
\hline Log Deaths per Capita & $-4.82(0.25)$ & $-4.63(0.30)$ & $-0.195(0.016)$ \\
\hline Log Births per Capita & $-4.24(0.20)$ & $-4.36(0.23)$ & $0.125(0.012)$ \\
\hline Log Social Security Recipients per Cap & $-1.93(0.25)$ & $-1.66(0.28)$ & $-0.265(0.014)$ \\
\hline Log People in Poverty per Capita & $-2.15(0.38)$ & $-2.04(0.40)$ & $-0.117(0.028)$ \\
\hline Log Public School Enrollment per Cap & $-1.84(0.17)$ & $-1.75(0.22)$ & $-0.091(0.012)$ \\
\hline Log Violent Crimes per Capita & $-5.37(0.86)$ & $-6.26(1.01)$ & $0.893(0.056)$ \\
\hline Log Robberies per Capita & $-6.72(1.25)$ & $-8.16(1.18)$ & $1.434(0.064)$ \\
\hline Log Property Crimes per Capita & $-3.16(0.57)$ & $-4.00(0.92)$ & $0.842(0.050)$ \\
\hline Log Motor Vehicle Thefts per Capita & $-5.48(0.93)$ & $-6.75(0.93)$ & $1.269(0.051)$ \\
\hline Region Northeast & $0.20(0.40)$ & $0.08(0.27)$ & $0.120(0.009)$ \\
\hline Region Midwest & $0.19(0.40)$ & $0.34(0.47)$ & $-0.143(0.016)$ \\
\hline Region South & $0.24(0.43)$ & $0.45(0.50)$ & $-0.201(0.017)$ \\
\hline Region West & $0.36(0.48)$ & $0.14(0.35)$ & $0.224(0.012)$ \\
\hline Observations & 818 & 127,954 & \\
\hline
\end{tabular}

$\overline{\text { Note: Time-varying variables are examined in the year before the terror attack(s) took place. Each observation is a year- }}$ county cell. Columns 1 and 2 restrict the sample to observations with a successful terror attack(s) and observations without a terror attack respectively. Standard deviations are in parentheses (standard errors for the last column). 


\section{Two-Sided $t$-tests}

\begin{tabular}{|c|c|c|c|}
\hline State Capital & $0.13(0.34)$ & $0.12(0.32)$ & $0.013(0.031)$ \\
\hline Coastal County & $0.63(0.48)$ & $0.59(0.49)$ & $0.034(0.045)$ \\
\hline Airport (Large Hub) & $0.29(0.46)$ & $0.33(0.47)$ & $-0.036(0.042)$ \\
\hline Airport (Medium Hub) & $0.14(0.35)$ & $0.13(0.34)$ & $0.011(0.032)$ \\
\hline Log Population & $12.99(1.41)$ & $13.00(1.59)$ & $-0.016(0.133)$ \\
\hline Log Deaths per Capita & $-4.82(0.25)$ & $-4.82(0.25)$ & $0.005(0.030)$ \\
\hline Log Births per Capita & $-4.24(0.20)$ & $-4.25(0.20)$ & $0.007(0.024)$ \\
\hline Log Social Security Recipients per Capita & $-1.93(0.25)$ & $-1.94(0.27)$ & $0.016(0.029)$ \\
\hline Log People in Poverty per Capita & $-2.15(0.38)$ & $-2.18(0.37)$ & $0.027(0.053)$ \\
\hline Log Public School Enrollment per Capita & $-1.84(0.17)$ & $-1.84(0.19)$ & $0.004(0.022)$ \\
\hline Log Violent Crimes per Capita & $-5.37(0.86)$ & $-5.41(1.08)$ & $0.038(0.111)$ \\
\hline Log Robberies per Capita & $-6.72(1.25)$ & $-6.60(1.36)$ & $-0.125(0.158)$ \\
\hline Log Property Crimes per Capita & $-3.16(0.57)$ & $-3.29(0.68)$ & $0.131(0.072)$ \\
\hline Log Motor Vehicle Thefts per Capita & $-5.48(0.93)$ & $-5.54(1.11)$ & $0.059(0.117)$ \\
\hline Region Northeast & $0.20(0.39)$ & $0.17(0.38)$ & $0.030(0.037)$ \\
\hline Region Midwest & $0.19(0.40)$ & $0.20(0.40)$ & $-0.010(0.037)$ \\
\hline Region South & $0.24(0.43)$ & $0.23(0.42)$ & $0.010(0.040)$ \\
\hline Region West & $0.36(0.48)$ & $0.39(0.49)$ & $-0.030(0.045)$ \\
\hline
\end{tabular}

$\overline{\text { Note: Time-varying variables are examined in the year before the terror attack(s) took place. Each observation is a year- }}$ county cell. Columns 1 and 2 restrict the sample to observations with a successful terror attack(s) and observations with a failed terror attack(s) respectively. Standard deviations are in parentheses (standard errors for the last column). 
Table 4: Predict Success of a Terror Attack

\begin{tabular}{|c|c|c|c|}
\hline$\overline{\text { Probit Regression }}$ & $\begin{array}{c}\text { Successful } \\
(1)\end{array}$ & $\begin{array}{c}\text { Successful } \\
(2)\end{array}$ & $\begin{array}{c}\text { Successful } \\
(3)\end{array}$ \\
\hline State Capital & $\begin{array}{c}0.017 \\
(0.018)\end{array}$ & $\begin{array}{c}0.076 \\
(0.047)\end{array}$ & $\begin{array}{c}0.054 \\
(0.047)\end{array}$ \\
\hline Coastal County & $\begin{array}{c}0.001 \\
(0.017)\end{array}$ & $\begin{array}{l}-0.002 \\
(0.048)\end{array}$ & $\begin{array}{l}-0.004 \\
(0.046)\end{array}$ \\
\hline Airport (Large Hub) & $\begin{array}{l}-0.026 \\
(0.018)\end{array}$ & $\begin{array}{l}-0.043 \\
(0.063)\end{array}$ & $\begin{array}{l}-0.046 \\
(0.069)\end{array}$ \\
\hline Airport (Medium Hub) & $\begin{array}{c}0.002 \\
(0.021)\end{array}$ & $\begin{array}{l}-0.101 \\
(0.086)\end{array}$ & $\begin{array}{l}-0.068 \\
(0.083)\end{array}$ \\
\hline Log Population & & $\begin{array}{l}-0.065 \\
(0.166)\end{array}$ & $\begin{array}{l}-0.001 \\
(0.172)\end{array}$ \\
\hline Log Births & & $\begin{array}{c}0.032 \\
(0.140)\end{array}$ & $\begin{array}{c}0.014 \\
(0.142)\end{array}$ \\
\hline Log Social Security Recipients & & $\begin{array}{c}0.050 \\
(0.085)\end{array}$ & $\begin{array}{l}-0.028 \\
(0.085)\end{array}$ \\
\hline Log Public School Enrollment & & $\begin{array}{c}0.004 \\
(0.144)\end{array}$ & $\begin{array}{l}-0.030 \\
(0.149)\end{array}$ \\
\hline Log Violent Crimes & & & $\begin{array}{c}0.063 \\
(0.059)\end{array}$ \\
\hline Log Robberies & & & $\begin{array}{l}-0.066 \\
(0.050)\end{array}$ \\
\hline Log Property Crimes & & & $\begin{array}{c}0.169 \\
(0.081)\end{array}$ \\
\hline Log Motor Vehicle Thefts & & & $\begin{array}{l}-0.061 \\
(0.063)\end{array}$ \\
\hline Non-U.S. Target & $\begin{array}{l}-0.008 \\
(0.028)\end{array}$ & $\begin{array}{c}0.034 \\
(0.106)\end{array}$ & $\begin{array}{c}0.017 \\
(0.111)\end{array}$ \\
\hline Logistically International & $\begin{array}{l}-0.012 \\
(0.051)\end{array}$ & $\begin{array}{l}-0.009 \\
(0.156)\end{array}$ & Dropped \\
\hline Number of Attacks & $\begin{array}{c}0.054 \\
(0.007)\end{array}$ & $\begin{array}{c}0.090 \\
(0.038)\end{array}$ & $\begin{array}{c}0.093 \\
(0.036)\end{array}$ \\
\hline Years & $1970-2013$ & 1989-2006 & 1989-2006 \\
\hline Region FE & $\checkmark$ & $\checkmark$ & $\checkmark$ \\
\hline Type Attack \& Weapon FE & $\checkmark$ & $\checkmark$ & $\checkmark$ \\
\hline Target FE & $\checkmark$ & $\checkmark$ & $\checkmark$ \\
\hline Observations & 960 & 388 & 357 \\
\hline Pseudo R-squared & 0.165 & 0.210 & 0.216 \\
\hline$F$-Test on Listed Variables ( $p$-value) & 0.34 & 0.89 & 0.47 \\
\hline
\end{tabular}

Note: This table reports marginal effects from a probit regression. Each observation is a year-county cell with at least one terror attacks. Robust standard errors are in parentheses, adjusted for clustering by county. The dependent variable is equal to one if at least one of the terror attacks is successful and zero if the attack(s) failed. Time-varying variables are examined in the year before the terror attack(s) took place. The $F$-Test on listed variables includes the region dummies. 
Table 5: Relationship Between Terrorism and Employment and Wages: 1970-2013

\begin{tabular}{|c|c|c|c|c|c|}
\hline & & & Jobs/P & & \\
\hline & (1) & (2) & (3) & (4) & (5) \\
\hline$\overline{P a n e l} A$ & & & & & \\
\hline Successful & $\begin{array}{l}-4.31 \\
(2.06)\end{array}$ & $\begin{array}{l}-3.89 \\
(2.17)\end{array}$ & $\begin{array}{l}-4.03 \\
(2.36)\end{array}$ & $\begin{array}{l}-5.82 \\
(2.76)\end{array}$ & $\begin{array}{l}-5.60 \\
(2.73)\end{array}$ \\
\hline R-squared & 0.469 & 0.472 & 0.544 & 0.623 & 0.653 \\
\hline & (1) & $\begin{array}{l}10 \\
(2)\end{array}$ & $\begin{array}{c}\operatorname{lig} \mathrm{Wa} \\
(3)\end{array}$ & (4) & (5) \\
\hline$\overline{\text { Panel B }}$ & & & & & \\
\hline Successful & $\begin{array}{l}-2.25 \\
(1.84)\end{array}$ & $\begin{array}{l}-2.12 \\
(1.85)\end{array}$ & $\begin{array}{c}-3.35 \\
(1.81)\end{array}$ & $\begin{array}{l}-4.21 \\
(2.06)\end{array}$ & $\begin{array}{l}-3.38 \\
(1.98)\end{array}$ \\
\hline R-squared & 0.500 & 0.504 & 0.594 & 0.656 & 0.775 \\
\hline $\begin{array}{l}\text { Year \& State FE } \\
\text { Region } \times \text { Year }\end{array}$ & $\checkmark$ & $\checkmark$ & $\begin{array}{l}\checkmark \\
\checkmark\end{array}$ & $\checkmark$ & $\checkmark$ \\
\hline $\begin{array}{l}\text { Division } \times \text { Year } \\
\text { Time-Invariant Controls }\end{array}$ & & & & $\checkmark$ & $\begin{array}{l}\checkmark \\
\checkmark\end{array}$ \\
\hline Type Attack FE & $\checkmark$ & $\checkmark$ & $\checkmark$ & $\checkmark$ & $\checkmark$ \\
\hline Weapon FE & $\checkmark$ & $\checkmark$ & $\checkmark$ & $\checkmark$ & $\checkmark$ \\
\hline Target FE & & $\checkmark$ & $\checkmark$ & $\checkmark$ & $\checkmark$ \\
\hline Observations & 960 & 960 & 960 & 960 & 960 \\
\hline
\end{tabular}

Note: Each entry is from a separate OLS regression. Robust standard errors are in parentheses, adjusted for clustering by county. In Panel A, the dependent variable is the log of the county-year ratio of jobs-to-population. In Panel $\mathrm{B}$, the dependent variable is the log of the county real average wage per job. The variable "Successful" is a dummy that is equal to one if the terror attack is successful in that county and year and zero if the terror attack failed. If there are many terror attacks, "Successful" is equal to one if at least one of the attacks succeeded. The controls include a dummy that is equal to one if the target is non-American, a dummy that is equal to one if the attack is logistically international and a variable that is equal to the number of terror attacks. Time-invariant controls include dummies for coastal counties and being a state capital and a dummy for whether the county has an airport. The time period is 1970-2013. 
Table 6: Relationship Between Terrorism and Employment and Wages: Intensity

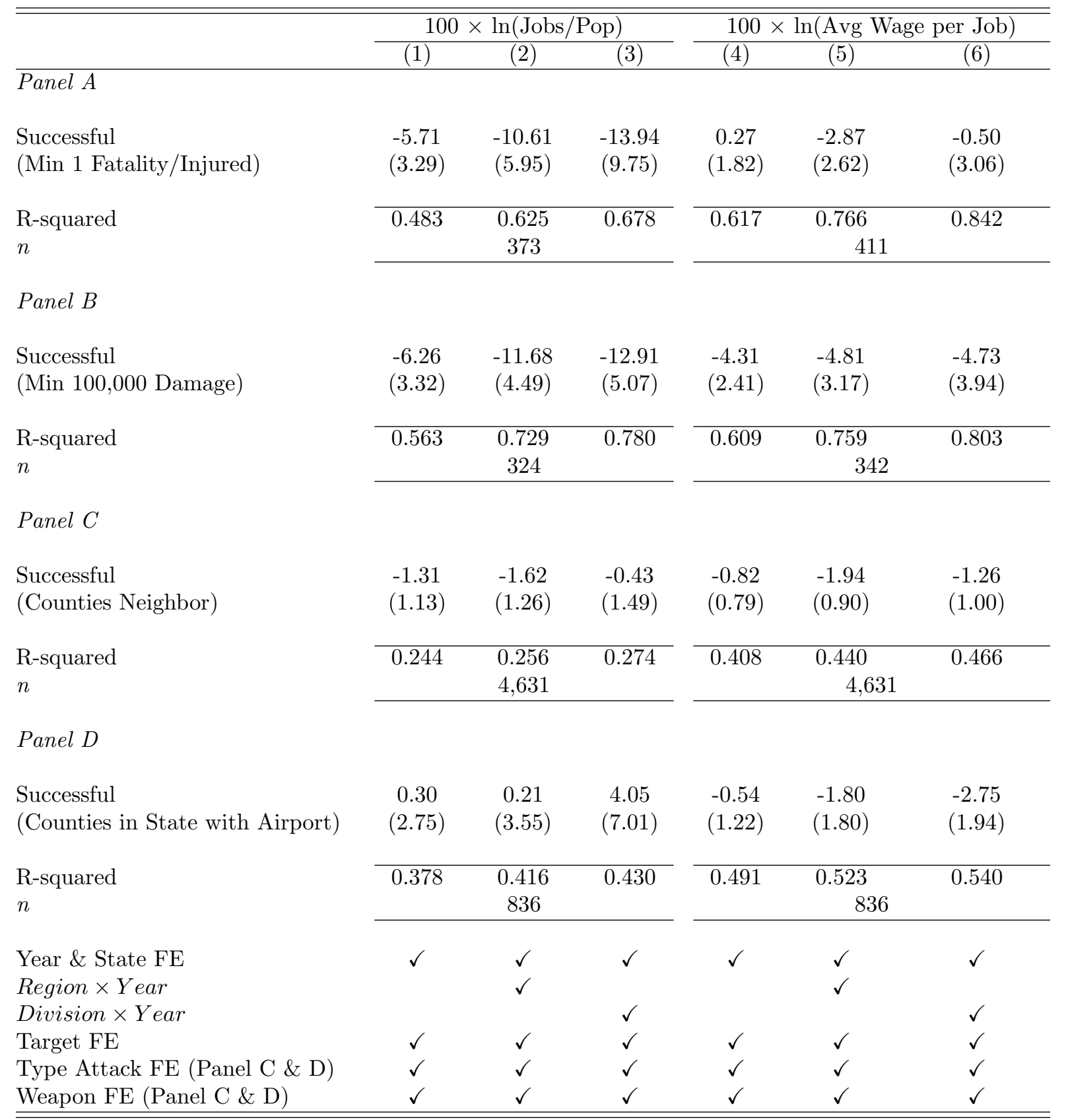

Note: Each entry is from a separate OLS regression. Robust standard errors are in parentheses, adjusted for clustering by county. In columns 1-3, the dependent variable is the log of the county-year ratio of jobs-to-population. In columns 4-6, the dependent variable is the log of the county real average wage per job. The variable "Successful" is a dummy that is equal to one if the terror attack is successful in that county and year and zero if the terror attack failed. If there are many terror attacks, "Successful" is equal to one if at least one of the attacks succeeded. Panel A restricts the sample to county-year observations in which the terror attack(s) failed or the terror attack(s) was successful and led to at least one fatality or injury. Panel B restricts the sample to county-year observations in which the terror attack(s) failed or the terror attack(s) was successful and led to a minimum of $\$ 100,000$. Panel $\mathrm{C}$ restricts the sample to neighboring counties instead of targeted counties. Panel D restricts the sample to non-targeted counties with an airport in the same state as targeted counties. The controls include a variable that is equal to the number of terror attacks. The time period is 1970-2013. 
Table 7: Relationship Between Terrorism and Employment: Duration Effects

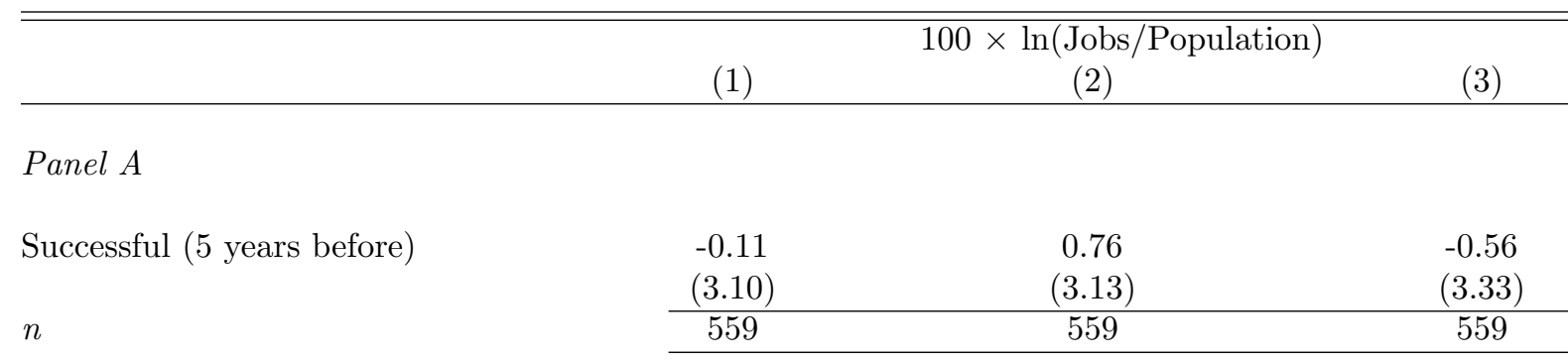

\section{Panel B}

Successful (3 years before)

\begin{tabular}{ccc}
1.65 & 2.49 & 1.18 \\
$(3.05)$ & $(3.09)$ & $(3.41)$ \\
\hline 596 & 559 & 559 \\
\hline
\end{tabular}

Panel C

Successful (1 year before)

\begin{tabular}{ccc}
-0.97 & -0.04 & -1.53 \\
$(2.69)$ & $(2.73)$ & $(3.24)$ \\
\hline 634 & 634 & 634 \\
\hline
\end{tabular}

Panel D

Successful

\begin{tabular}{ccc}
-4.31 & -4.03 & -5.82 \\
$(2.06)$ & $(2.36)$ & $(2.76)$ \\
\hline 960 & 960 & 960 \\
\hline
\end{tabular}

Panel E

Successful (1 year after)

\begin{tabular}{ccc}
-4.23 & -4.45 & -5.78 \\
$(2.11)$ & $(2.41)$ & $(2.76)$ \\
\hline 947 & 947 & 947 \\
\hline
\end{tabular}

$n$

Panel F

Successful (3 years after)

\begin{tabular}{ccc}
-1.29 & -1.22 & -2.99 \\
$(2.32)$ & $(2.64)$ & $(3.14)$ \\
\hline 939 & 939 & 939 \\
\hline
\end{tabular}

$n$

Panel G

Successful (5 years after)

\begin{tabular}{ccc}
-0.20 & 0.93 & -1.91 \\
$(2.49)$ & $(2.41)$ & $(2.91)$ \\
\hline 944 & 944 & 944 \\
\hline & & \\
$\checkmark$ & $\checkmark$ & $\checkmark$ \\
& & $\checkmark$ \\
$\checkmark$ & $\checkmark$ & $\checkmark$ \\
$\checkmark$ & $\checkmark$ & $\checkmark$
\end{tabular}

Year \& State FE

Region $\times$ Year

Type Attack FE

Weapon FE

Target FE

Note: Each entry is from a separate OLS regression. Robust standard errors are in parentheses, adjusted for clustering by county. The dependent variable is the log of the county-year ratio of jobs-to-population. This table shows estimates for five years before the attack, three years before the attack, one year before the attack, the year of the attack, the year after the attack, three years after the attack and five years after the attack. The variable "Successful" is a dummy that is equal to one if the terror attack is successful in that county and year and zero if the terror attack failed. If there are many terror attacks, "Successful" is equal to one if at least one of the attacks succeeded. The controls include a dummy that is equal to one if the target is non-American, a dummy that is equal to one if the attack is logistically international and a variable that is equal to the number of terror attacks. Panels $\mathrm{A}, \mathrm{B}$ and $\mathrm{C}$ restrict the sample to observations in which there was not a terror attack. The time period is 1970-2013. 


\begin{tabular}{|c|c|c|c|c|c|}
\hline & \multicolumn{5}{|c|}{$\ln$ (Terror Searches) } \\
\hline & (1) & $(2)$ & $(3)$ & $(4)$ & $(5)$ \\
\hline Successful & $\begin{array}{c}0.531 \\
(0.260)\end{array}$ & $\begin{array}{c}0.542 \\
(0.263)\end{array}$ & $\begin{array}{c}0.611 \\
(0.278)\end{array}$ & $\begin{array}{c}0.715 \\
(0.348)\end{array}$ & $\begin{array}{c}0.706 \\
(0.351)\end{array}$ \\
\hline $\ln (\mathrm{n})$ & 0.219 & 0.216 & 0.209 & 0.234 & 0.186 \\
\hline "City State Year" & $(0.050)$ & $(0.049)$ & $(0.056)$ & $(0.065)$ & $(0.071)$ \\
\hline Year \& State FE & $\checkmark$ & $\checkmark$ & $\checkmark$ & $\checkmark$ & $\checkmark$ \\
\hline Region $\times$ Year & & & $\checkmark$ & & \\
\hline Division $\times$ Year & & & & $\checkmark$ & $\checkmark$ \\
\hline Time-Invariant Controls & & & & & $\checkmark$ \\
\hline Type Attack FE & $\checkmark$ & $\checkmark$ & $\checkmark$ & $\checkmark$ & $\checkmark$ \\
\hline Weapon FE & $\checkmark$ & $\checkmark$ & $\checkmark$ & $\checkmark$ & $\checkmark$ \\
\hline Target FE & & $\checkmark$ & $\checkmark$ & $\checkmark$ & $\checkmark$ \\
\hline Observations & 338 & 338 & 338 & 338 & 338 \\
\hline R-squared & 0.506 & 0.507 & 0.580 & 0.661 & 0.665 \\
\hline
\end{tabular}

Note: Robust standard errors are in parentheses, adjusted for clustering by county. The dependent variable is the log of counts of Google searches for the words "city", "state", "year" and "terrorism". The variable "ln(n)" is the log of counts of Google searches for the words "city", "state" and "year". The variable "Successful" is a dummy that is equal to one if the terror attack is successful in that county and year and zero if the terror attack failed. If there are many terror attacks, "Successful" is equal to one if at least one of the attacks succeeded. The controls include a dummy that is equal to one if the target is non-American, a dummy that is equal to one if the attack is logistically international and a variable that is equal to the number of terror attacks. Time-invariant controls include dummies for coastal counties and being a state capital and a dummy for whether the county has an airport. The time period is 1994-2013, 2001 is excluded.

Table 9: Relationship Between Terrorism and Consumer Sentiment: 2000-2012

\begin{tabular}{lcccc}
\hline \hline & Personal & Business & Personal & Bad Time \\
& $\begin{array}{c}\text { Finances } \\
\text { Worse Now }\end{array}$ & $\begin{array}{c}\text { Conditions } \\
\text { Worse Now }\end{array}$ & $\begin{array}{c}\text { Finances } \\
\text { Worse Future }\end{array}$ & $\begin{array}{c}\text { Buy Major } \\
\text { HH Items }\end{array}$ \\
& $(1)$ & $(2)$ & $(3)$ & $(4)$ \\
\hline & & & & \\
& 0.266 & 0.154 & $(0.032)$ & $(0.035)$ \\
Successful & $(0.067)$ & $(0.036)$ & $\checkmark$ & $\checkmark$ \\
Socioeconomic Controls & & & $\checkmark$ & $\checkmark$ \\
Year \& State FE & $\checkmark$ & $\checkmark$ & $\checkmark$ & $\checkmark$ \\
Type Attack \& Weapon FE & $\checkmark$ & $\checkmark$ & 1,04 & $\checkmark$ \\
Target FE & $\checkmark$ & $\checkmark$ & 0.053 & 1,674 \\
Observations & $\checkmark$ & 1,755 & 0.081 \\
Pseudo R-Squared & 1,775 & 0.132 & & $\checkmark$ \\
\hline \hline
\end{tabular}

$\overline{\text { Note: This table reports marginal effects from a probit regression. Household head sampling weights are used. In column 1, }}$ the dependent variable is based on answers to the question: "We are interested in how people are getting along financially these days. Would you say that you are better off or worse off financially than you were a year ago?" The dependent variable is equal to one if respondents report "Worse" and zero otherwise. In column 2, the dependent variable is based on answers to the question: "Would you say that at the present time business conditions are better or worse than they were a year ago?" The dependent variable is equal to one if respondents report "Worse now" and zero otherwise. In column 3, the dependent variable is based on answers to the question: "Now looking ahead-do you think that a year from now you will be better off financially, or worse off, or just about the same as now?" The dependent variable is equal to one if respondents report "Will be worse off" and zero otherwise. In column 4, the dependent variable is based on answers to the question: "About the big things people buy for their homes-such as furniture, a refrigerator, stove, television, and things like that. Generally speaking, do you think now is a good or a bad time for people to buy major household items?" The dependent variable is equal to one if respondents report "Bad" and zero otherwise. The variable "Successful" is a dummy that is equal to one if the terror attack is successful in that county and year and zero if the terror attack failed. If there are many terror attacks, "Successful" is equal to one if at least one of the attacks succeeded. The controls include a dummy that is equal to one if the target is non-American, a dummy that is equal to one if the attack is logistically international and a variable that is equal to the number of terror attacks. The time period is 2000-2012. 


\section{Appendix: NOT FOR PUBLICATION}

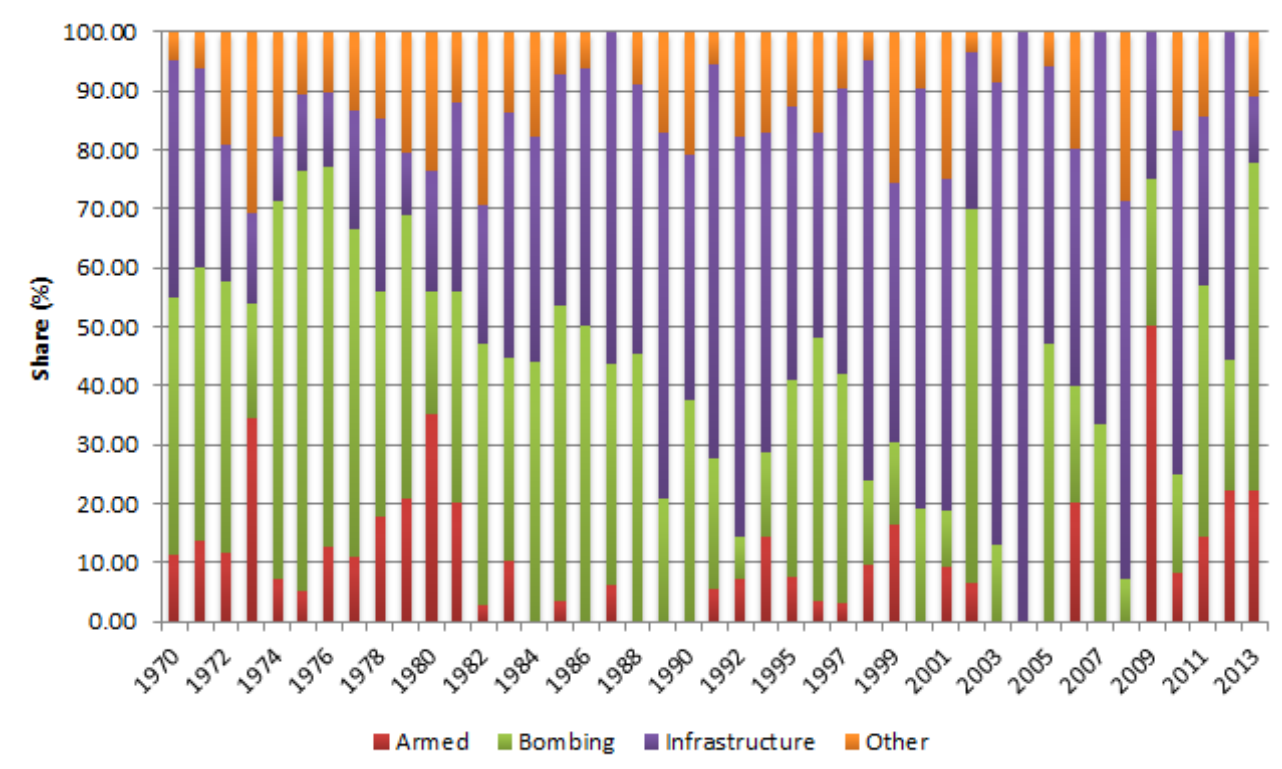

Figure A1: Share of terror attacks involving the following general methods of attack: armed assault, bombing/explosion, facility/infrastructure and other. Attack types classified as "Other" include assassination, hijacking, barricade hostage, kidnapping and unarmed assault. 


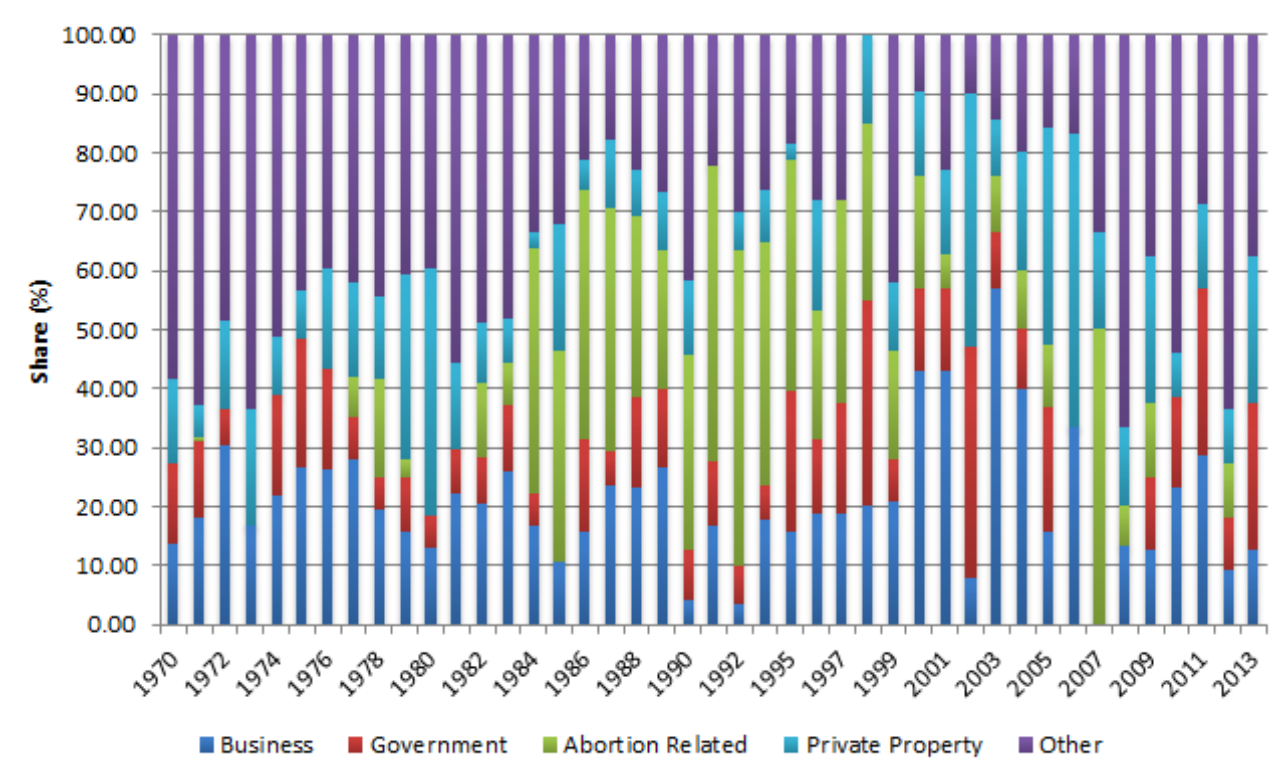

Figure A2: Share of terror attacks targeting the following victims: business, government, abortion clinics or employees, private citizens and property and other. Targets classified as "Other" include airports, educational and religious institutions, transportation, media, military, NGO, police, telecommunication, tourists and attacks carried out against foreign missions, maritime facilities, non-state militias, violent political parties, utilities and food or water supply.

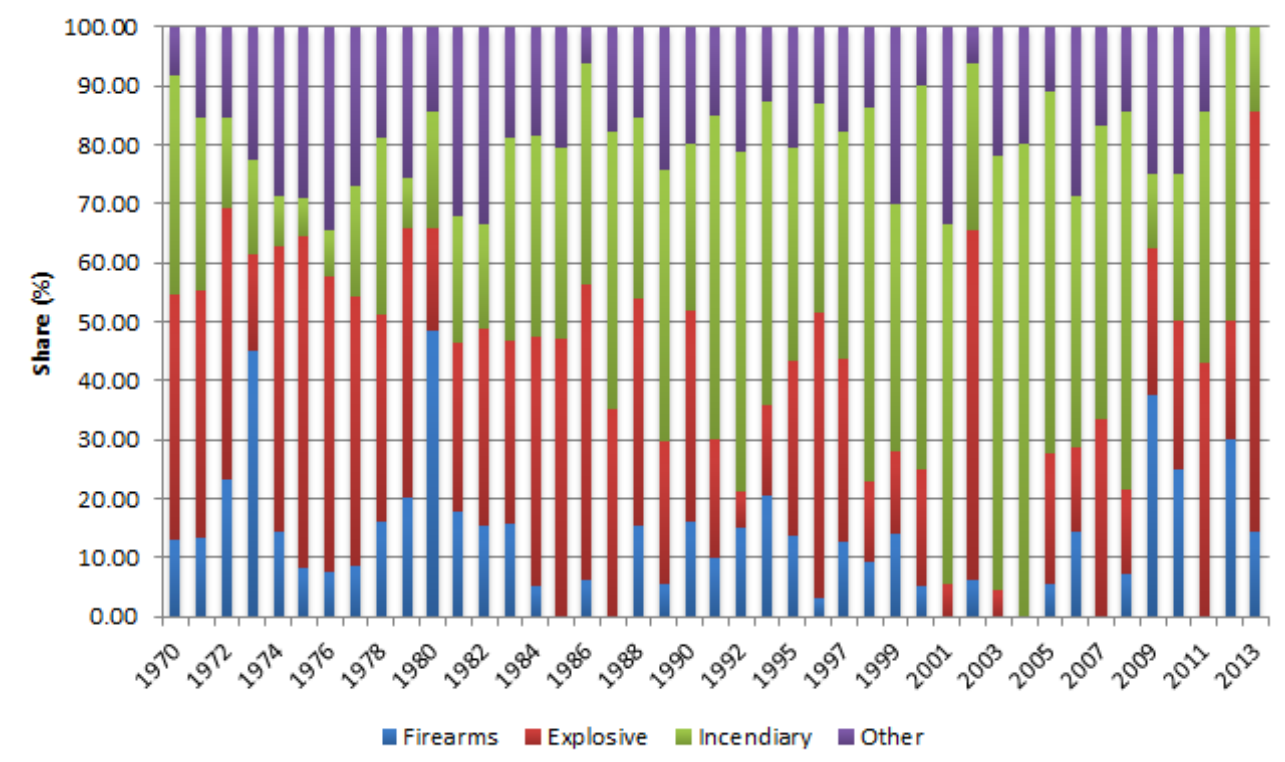

Figure A3: Share of terror attacks by the general type of weapon used: firearms, explosives, bombs or dynamite, incendiary and other. Weapons classified as "Other" are either (1) weapons that have been identified but does not fit into one of the categories or (2) weapons that could not have been identified. 


\begin{tabular}{|c|c|c|c|c|c|c|}
\hline & \multirow[b]{2}{*}{ Observation } & \multirow[b]{2}{*}{ Percentage } & \multirow{2}{*}{$\begin{array}{c}\text { Attack } \\
\text { Success }\end{array}$} & \multicolumn{3}{|c|}{ If Attack Successful (mean) } \\
\hline & & & & Injured & Killed & Damage \\
\hline \multicolumn{7}{|l|}{ Attack Type } \\
\hline Assassination & 70 & $7.3 \%$ & $77.1 \%$ & 0.76 & 1.26 & 150,667 \\
\hline Armed Assault & 112 & $11.7 \%$ & $95.5 \%$ & 2.86 & 1.28 & 483,901 \\
\hline Bombing & 419 & $43.8 \%$ & $81.9 \%$ & 2.56 & 0.29 & 669,620 \\
\hline Infrastructure & 460 & $48.1 \%$ & $93.4 \%$ & 0.87 & 0.14 & 895,242 \\
\hline Unarmed & 33 & $3.5 \%$ & $51.5 \%$ & 50.75 & 0.35 & 2,946 \\
\hline \multirow[t]{3}{*}{ Other \& Unknown } & 32 & $3.3 \%$ & $93.8 \%$ & 1.00 & 0.83 & 360,750 \\
\hline & & & Attack & \multicolumn{3}{|c|}{ If Attack Successful (mean) } \\
\hline & Observations & Percentage & Success & Injured & Killed & Damage \\
\hline \multicolumn{7}{|l|}{ Target } \\
\hline Business & 257 & $26.9 \%$ & $92.2 \%$ & 4.95 & 0.32 & $1,286,966$ \\
\hline Government & 174 & $18.2 \%$ & $79.3 \%$ & 6.89 & 0.28 & 582,233 \\
\hline Abortion Related & 168 & $17.6 \%$ & $88.1 \%$ & 0.16 & 0.03 & 184,814 \\
\hline Airport & 33 & $3.5 \%$ & $87.9 \%$ & 7.97 & 1.10 & 482,102 \\
\hline Educational Inst & 100 & $10.5 \%$ & $81.0 \%$ & 1.73 & 0.25 & $1,027,569$ \\
\hline Private Property & 181 & $18.9 \%$ & $86.7 \%$ & 3.61 & 0.64 & $1,200,410$ \\
\hline Religious Inst & 57 & $6.0 \%$ & $89.5 \%$ & 0.71 & 0.69 & 496,292 \\
\hline \multirow[t]{3}{*}{ Other \& Unknown } & 267 & $27.9 \%$ & $90.3 \%$ & 5.21 & 0.49 & 482,688 \\
\hline & & & Attack & \multicolumn{3}{|c|}{ If Attack Successful (mean) } \\
\hline & Observations & Percentage & Success & Injured & Killed & Damage \\
\hline \multicolumn{7}{|l|}{ Weapon } \\
\hline Firearms & 161 & $16.8 \%$ & $90.7 \%$ & 2.17 & 1.19 & 429,687 \\
\hline Explosives & 419 & $43.8 \%$ & $82.1 \%$ & 2.58 & 0.33 & 686,490 \\
\hline Incendiary & 438 & $45.8 \%$ & $93.3 \%$ & 0.62 & 0.12 & 928,632 \\
\hline Melee & 26 & $2.7 \%$ & $96.2 \%$ & 2.12 & 1.08 & 362,142 \\
\hline Sabotage & 28 & $2.9 \%$ & $96.4 \%$ & 4.04 & 0.11 & 352,232 \\
\hline Other \& Unknown & 168 & $17.6 \%$ & $76.7 \%$ & 8.18 & 0.62 & 880,784 \\
\hline Multiple Attacks & 301 & $31.5 \%$ & $94.0 \%$ & 5.35 & 0.46 & 842,006 \\
\hline Target Non-US & 84 & $8.8 \%$ & $88.1 \%$ & 3.13 & 0.81 & 424,348 \\
\hline Logistic Int'l & 49 & $5.1 \%$ & $83.7 \%$ & 2.76 & 0.66 & 680,512 \\
\hline Total Observations & 956 & & $85.7 \%$ & 2.43 & 0.30 & 791,183 \\
\hline
\end{tabular}

Notes: There are a total of 960 county-year observations. Sept. 11, 2001 and Oklahoma City bombing are excluded. In this table, the variable "Multiple Attacks" equals one if there is more than one terror attack in a given county-year cell. For some terror attacks, multiple weapons were used. Moreover, up to three attack types and target information can be recorded by incident. Weapons classified as "Others \& Unknown" are either (1) weapons that have been identified but does not fit into one of the categories or (2) weapons that could not have been identified. Targets classified as "Others \& Unknown" include media, military, NGO, police, telecommunication, tourists, transportation and attacks carried out against foreign missions, maritime facilities, non-state militias, violent political parties, utilities and food or water supply. Note that an unarmed assault is an attack whose primary objective is to cause physical harm or death directly. Unarmed assaults include chemical, biological and radiological weapons but exclude explosive, firearm and incendiary. Attacks classified as infrastructure refers to an act whose primary objective is to cause damage to a non-human target (building, monument, train or pipeline). The attack type "Hijacking" is included in the category "Other \& Unknown". The last three columns restrict the sample to successful terror attacks. Property damages are in constant 2005 U.S. dollar. 
Table A2: Robustness Checks: Omission of a Subset of Attacks

\begin{tabular}{|c|c|c|c|c|}
\hline & \multicolumn{4}{|c|}{$100 \times \ln ($ Jobs/Population $)$} \\
\hline Successful & $\begin{array}{l}-3.50 \\
(2.17)\end{array}$ & $\begin{array}{l}-4.04 \\
(2.12)\end{array}$ & $\begin{array}{l}-3.79 \\
(2.01)\end{array}$ & $\begin{array}{l}-4.39 \\
(2.03)\end{array}$ \\
\hline Year Omitted & 1970 & 1971 & 1972 & 1973 \\
\hline Successful & $\begin{array}{l}-4.21 \\
(2.11)\end{array}$ & $\begin{array}{l}-4.01 \\
(2.12)\end{array}$ & $\begin{array}{l}-4.29 \\
(2.09)\end{array}$ & $\begin{array}{l}-4.31 \\
(2.06)\end{array}$ \\
\hline Year Omitted & 1974 & 1975 & 1976 & 1977 \\
\hline Successful & $\begin{array}{l}-4.31 \\
(2.06)\end{array}$ & $\begin{array}{l}-4.31 \\
(2.06)\end{array}$ & $\begin{array}{l}-3.97 \\
(2.20)\end{array}$ & $\begin{array}{l}-3.88 \\
(2.15)\end{array}$ \\
\hline Year Omitted & 1978 & 1979 & 1980 & 1981 \\
\hline Successful & $\begin{array}{l}-4.67 \\
(2.12)\end{array}$ & $\begin{array}{l}-4.07 \\
(2.09)\end{array}$ & $\begin{array}{l}-4.06 \\
(1.99)\end{array}$ & $\begin{array}{l}-5.04 \\
(2.06)\end{array}$ \\
\hline Year Omitted & 1982 & 1983 & 1984 & 1985 \\
\hline Successful & $\begin{array}{l}-4.33 \\
(2.12)\end{array}$ & $\begin{array}{l}-4.32 \\
(2.08)\end{array}$ & $\begin{array}{l}-4.63 \\
(2.10)\end{array}$ & $\begin{array}{l}-4.03 \\
(2.07)\end{array}$ \\
\hline Year Omitted & 1986 & 1987 & 1988 & 1989 \\
\hline Successful & $\begin{array}{l}-4.25 \\
(2.06)\end{array}$ & $\begin{array}{l}-4.17 \\
(2.11)\end{array}$ & $\begin{array}{l}-3.72 \\
(2.24)\end{array}$ & $\begin{array}{l}-4.31 \\
(2.06)\end{array}$ \\
\hline Year Omitted & 1990 & 1991 & 1992 & 1993 \\
\hline Successful & $\begin{array}{l}-4.95 \\
(2.17)\end{array}$ & $\begin{array}{l}-4.30 \\
(2.17)\end{array}$ & $\begin{array}{l}-4.73 \\
(2.14)\end{array}$ & $\begin{array}{l}-5.54 \\
(2.13)\end{array}$ \\
\hline Year Omitted & 1994 & 1995 & 1996 & 1997 \\
\hline Successful & $\begin{array}{l}-4.72 \\
(2.10)\end{array}$ & $\begin{array}{l}-3.27 \\
(2.27)\end{array}$ & $\begin{array}{l}-4.37 \\
(2.10)\end{array}$ & $\begin{array}{l}-5.40 \\
(2.05)\end{array}$ \\
\hline Year Omitted & 1998 & 1999 & 2000 & 2001 \\
\hline Successful & $\begin{array}{l}-4.83 \\
(2.12)\end{array}$ & $\begin{array}{l}-4.30 \\
(2.07)\end{array}$ & $\begin{array}{l}-4.09 \\
(2.09)\end{array}$ & $\begin{array}{l}-4.37 \\
(2.08)\end{array}$ \\
\hline Year Omitted & 2002 & 2003 & 2004 & 2005 \\
\hline Successful & $\begin{array}{l}-4.35 \\
(2.07)\end{array}$ & $\begin{array}{l}-4.40 \\
(2.07)\end{array}$ & $\begin{array}{l}-4.86 \\
(2.05)\end{array}$ & $\begin{array}{l}-4.45 \\
(2.08)\end{array}$ \\
\hline Year Omitted & 2006 & 2007 & 2008 & 2009 \\
\hline Successful & $\begin{array}{l}-3.72 \\
(2.15)\end{array}$ & $\begin{array}{l}-3.93 \\
(2.05)\end{array}$ & $\begin{array}{l}-4.31 \\
(2.06)\end{array}$ & $\begin{array}{l}-4.21 \\
(2.07)\end{array}$ \\
\hline Year Omitted & 2010 & 2011 & 2012 & 2013 \\
\hline Year \& State FE & $\checkmark$ & $\checkmark$ & $\checkmark$ & $\checkmark$ \\
\hline Type Attack FE & $\checkmark$ & $\checkmark$ & $\checkmark$ & $\checkmark$ \\
\hline Weapon FE & $\checkmark$ & $\checkmark$ & $\checkmark$ & $\checkmark$ \\
\hline
\end{tabular}


Table A3: Robustness Checks: Omission of Terrorist Groups

\begin{tabular}{|c|c|c|c|c|c|}
\hline & & 100 & obs/Pop & & \\
\hline & $\begin{array}{c}\text { Omit } \\
\text { Environment } \\
\text { Animal } \\
(1)\end{array}$ & $\begin{array}{l}\text { Omit } \\
\text { Abortion } \\
(2)\end{array}$ & $\begin{array}{l}\text { Omit } \\
\text { Islamic } \\
(3)\end{array}$ & $\begin{array}{c}\text { Omit } \\
\text { Three } \\
\text { Types } \\
(4)\end{array}$ & $\begin{array}{c}\text { Omit } \\
\text { Catastrophic } \\
\text { Attacks } \\
(5)\end{array}$ \\
\hline Panel $A$ & & & & & \\
\hline Successful & $\begin{array}{l}-5.25 \\
(2.82)\end{array}$ & $\begin{array}{l}-6.69 \\
(2.78)\end{array}$ & $\begin{array}{l}-4.21 \\
(2.34)\end{array}$ & $\begin{array}{l}-7.76 \\
(3.20)\end{array}$ & $\begin{array}{l}-4.30 \\
(2.45)\end{array}$ \\
\hline R-squared & 0.567 & 0.577 & 0.543 & 0.603 & 0.551 \\
\hline & $\begin{array}{c}\text { Omit } \\
\text { Environment } \\
\text { Animal } \\
(1)\end{array}$ & $\begin{array}{c}100 \times \\
\text { Omit } \\
\text { Abortion } \\
(2)\end{array}$ & $\begin{array}{c}g \text { Wage } \\
\text { Omit } \\
\text { Islamic } \\
(3)\end{array}$ & $\begin{array}{l}\text { b) } \\
\text { Omit } \\
\text { Three } \\
\text { Types } \\
(4)\end{array}$ & $\begin{array}{c}\text { Omit } \\
\text { Catastrophic } \\
\text { Attacks } \\
(5)\end{array}$ \\
\hline Panel B & & & & & \\
\hline Successful & $\begin{array}{l}-2.60 \\
(1.70)\end{array}$ & $\begin{array}{l}-3.34 \\
(1.99)\end{array}$ & $\begin{array}{l}-3.27 \\
(1.82)\end{array}$ & $\begin{array}{c}-3.43 \\
(1.76)\end{array}$ & $\begin{array}{l}-3.32 \\
(1.82)\end{array}$ \\
\hline R-squared & 0.656 & 0.637 & 0.578 & 0.701 & 0.598 \\
\hline Year \& State FE & $\checkmark$ & $\checkmark$ & $\checkmark$ & $\checkmark$ & $\checkmark$ \\
\hline Region $\times$ Year & $\checkmark$ & $\checkmark$ & $\checkmark$ & $\checkmark$ & $\checkmark$ \\
\hline Type Attack FE & $\checkmark$ & $\checkmark$ & $\checkmark$ & $\checkmark$ & $\checkmark$ \\
\hline Weapon FE & $\checkmark$ & $\checkmark$ & $\checkmark$ & $\checkmark$ & $\checkmark$ \\
\hline Target FE & & $\checkmark$ & $\checkmark$ & $\checkmark$ & $\checkmark$ \\
\hline Observations & 817 & 795 & 945 & 637 & 945 \\
\hline
\end{tabular}

Note: Each entry is from a separate OLS regression. Robust standard errors are in parentheses, adjusted for clustering by county. In Panel $\mathrm{A}$, the dependent variable is the $\log$ of the county-year ratio of jobs-to-population. In Panel B, the dependent variable is the log of the county real average wage per job. In column 1, I omit terror attacks from environmentalism and animal protection groups. In column 2, I exclude terror attacks from anti-abortion groups. Column 3 excludes terror attacks from Islamic groups. In column 4, I exclude terror attacks from Islamic, environmentalism, animal protection and anti-abortion groups. In column 5 , I omit terror attacks leading to over $\$ 1$ billion or 100 deaths. The variable "Successful" is a dummy that is equal to one if the terror attack is successful in that county and year and zero if the terror attack failed. If there are many terror attacks, "Successful" is equal to one if at least one of the attacks succeeded. The controls include a dummy that is equal to one if the target is non-American, a dummy that is equal to one if the attack is logistically international and a variable that is equal to the number of terror attacks. Time-invariant controls include dummies for coastal counties and being a state capital and a dummy for whether the county has an airport. The time period is $1970-2013$. 
Table A4: Relationship Between Terrorism and Population: 1970-2013

\begin{tabular}{|c|c|c|c|c|c|}
\hline & \multicolumn{5}{|c|}{ ln(Population) } \\
\hline & $(1)$ & $(2)$ & $(3)$ & $(4)$ & $(5)$ \\
\hline Successful & $\begin{array}{c}-0.098 \\
(0.108)\end{array}$ & $\begin{array}{c}-0.088 \\
(0.108)\end{array}$ & $\begin{array}{c}-0.120 \\
(0.126)\end{array}$ & $\begin{array}{c}-0.202 \\
(0.144)\end{array}$ & $\begin{array}{c}-0.123 \\
(0.110)\end{array}$ \\
\hline Year \& State FE & $\checkmark$ & $\checkmark$ & $\checkmark$ & $\checkmark$ & $\checkmark$ \\
\hline Region $\times$ Year & & & $\checkmark$ & & \\
\hline Division $\times$ Year & & & & $\checkmark$ & $\checkmark$ \\
\hline Time-Invariant Controls & & & & & $\checkmark$ \\
\hline Type Attack FE & $\checkmark$ & $\checkmark$ & $\checkmark$ & $\checkmark$ & $\checkmark$ \\
\hline Weapon FE & $\checkmark$ & $\checkmark$ & $\checkmark$ & $\checkmark$ & $\checkmark$ \\
\hline Target FE & & $\checkmark$ & $\checkmark$ & $\checkmark$ & $\checkmark$ \\
\hline Observations & 960 & 960 & 960 & 960 & 960 \\
\hline R-squared & 0.430 & 0.434 & 0.483 & 0.551 & 0.753 \\
\hline
\end{tabular}

Note: Robust standard errors are in parentheses, adjusted for clustering by county. The dependent variable is the log of population. The variable "Successful" is a dummy that is equal to one if the terror attack is successful in that county and year and zero if the terror attack failed. If there are many terror attacks, "Successful" is equal to one if at least one of the attacks succeeded. The controls include a dummy that is equal to one if the target is non-American a dummy that is equal to one if the attack is logistically international and a variable that is equal to the number of terror attacks. Time-invariant controls include dummies for coastal counties and being a state capital and a dummy for whether the county has an airport. The time period is 1970-2013. 